Article

\title{
Polyhydroxyalkanoate Production on Waste Water Treatment Plants: Process Scheme, Operating Conditions and Potential Analysis for German and European Municipal Waste Water Treatment Plants
}

\author{
Timo Pittmann ${ }^{1, *}$ and Heidrun Steinmetz ${ }^{2}$ \\ 1 TBF + Partner AG, Herrenberger Strasse 14, 71032 Boeblingen, Germany \\ 2 Department of Resource Efficient Wastewater Technology, University of Kaiserslautern, Paul-Ehrlich-Str. 14, \\ 67663 Kaiserslautern, Germany; heidrun.steinmetz@bauing.uni-kl.de \\ * Correspondence: pit@tbf.ch; Tel.: +49-7031-23806-60
}

Academic Editor: Martin Koller

Received: 28 April 2017; Accepted: 3 June 2017; Published: 6 June 2017

\begin{abstract}
This work describes the production of polyhydroxyalkanoates (PHA) as a side stream process on a municipal waste water treatment plant (WWTP) and a subsequent analysis of the production potential in Germany and the European Union (EU). Therefore, tests with different types of sludge from a WWTP were investigated regarding their volatile fatty acids (VFA) production-potential. Afterwards, primary sludge was used as substrate to test a series of operating conditions (temperature, $\mathrm{pH}$, retention time (RT) and withdrawal (WD)) in order to find suitable settings for a high and stable VFA production. In a second step, various tests regarding a high PHA production and stable PHA composition to determine the influence of substrate concentration, temperature, $\mathrm{pH}$ and cycle time of an installed feast/famine-regime were conducted. Experiments with a semi-continuous reactor operation showed that a short RT of 4 days and a small WD of $25 \%$ at $\mathrm{pH}=6$ and around $30{ }^{\circ} \mathrm{C}$ is preferable for a high VFA production rate (PR) of $1913 \mathrm{mg}$ VFA $/(\mathrm{L} \times \mathrm{d})$ and a stable VFA composition. A high PHA production up to $28.4 \%$ of cell dry weight (CDW) was reached at lower substrate concentration, $20{ }^{\circ} \mathrm{C}$, neutral $\mathrm{pH}$-value and a $24 \mathrm{~h}$ cycle time. A final step a potential analysis, based on the results and detailed data from German waste water treatment plants, showed that the theoretically possible production of biopolymers in Germany amounts to more than 19\% of the 2016 worldwide biopolymer production. In addition, a profound estimation regarding the EU showed that in theory about $120 \%$ of the worldwide biopolymer production (in 2016) could be produced on European waste water treatment plants.
\end{abstract}

Keywords: biopolymer; municipal sewage plant; PHA; primary sludge; VFA

\section{Introduction}

Common plastic is derived from petrochemicals based on the limited natural resource petroleum. Besides the exploitation of natural resources, the use of plastic is responsible for major waste problems, as common plastic is non- or poor biodegradable [1].

Biopolymers present a possible alternative to common plastics. If they are fully biodegradable $[2,3]$ their use not only allows the preservation of limited resources, but also suits the idea of sustainability.

The term "biopolymer" or "bioplastic" is not yet uniformly defined. Common definitions of the term "biopolymer" also include biodegradable plastics from fossil fuels and non-biodegradable plastics from renewable resources as seen in Figure 1. To eliminate the problems accompanied by polymer production from crude oil a more stringent definition is introduced by the authors: 
"Biopolymers are made from renewable resources and/or biodegradable waste materials (e.g., waste water, sewage sludge, organic waste) and are fully biodegradable by naturally occurring microorganisms."

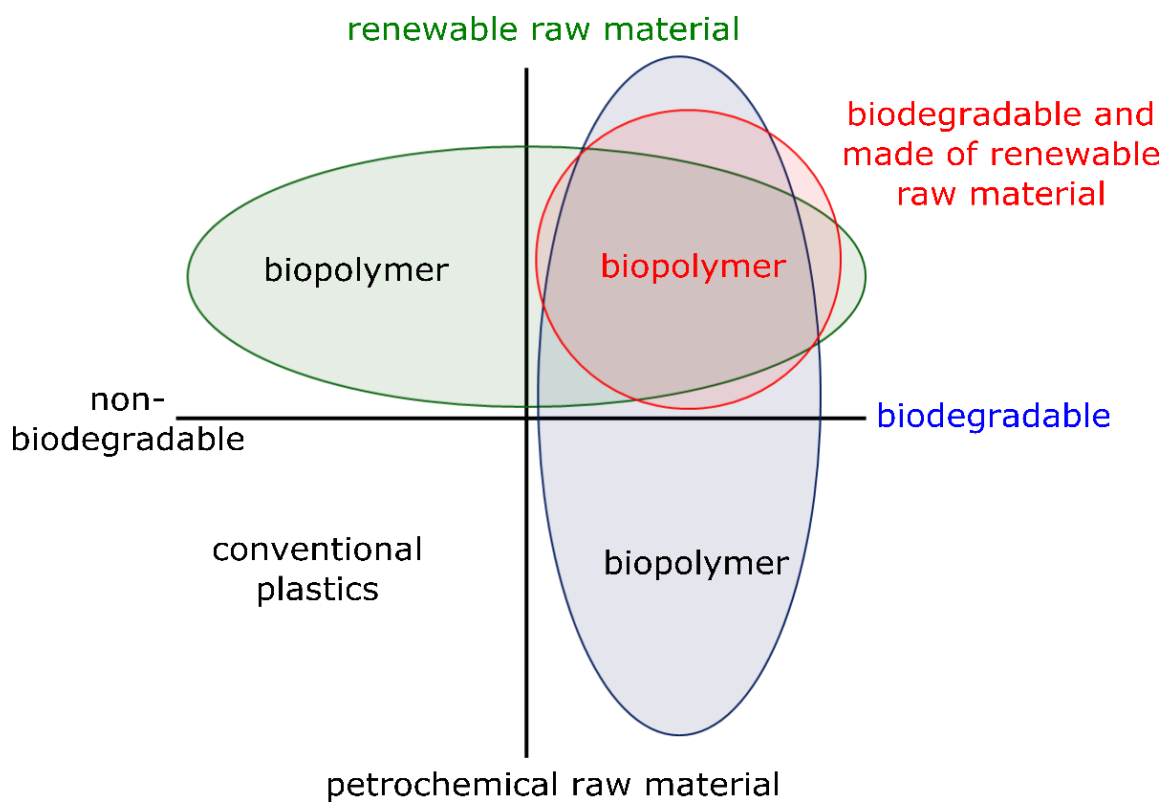

Figure 1. Definition for biopolymers, including the stringent definition on the upper right, modified after [4].

This definition ensures that polymers from fossil resources and non-biodegradable polymers, which cause at least one of the mentioned problems, are excluded and that the term biopolymer is just used for polymers, which allow the preservation of limited resources and also suit the idea of sustainability. This type of biopolymers is shown in the upper right of Figure 1.

Beside other polymers polyhydroxyalkanoates (PHA), which are biodegradable polyesters accumulated by bacteria under nutrient limited conditions [5] or under balanced growth, are a source for bioplastic production matching the above mentioned strict definition. More than 150 component parts of PHA have been identified so far [6]. The possibility for chemical modification of PHA provide a wide range of material properties and an even wider range of use $[7,8]$. However, so far the main raw material for the biopolymer production are starchy plants like maize [9], constituting the disadvantages of high land consumption, diminishing food resources as well as problems like leaching of nutrients, input of pesticide and soil erosion [10].

So far, municipal waste water treatment plants (WWTP) as alternative raw material and biomass source for the PHA production have not been widely investigated, although they offer the opportunity to compensate the disadvantages of the common PHA production using starchy plants.

PHA production in WWTP takes place in two steps, which composes the production of volatile fatty acids (VFA) in an anaerobic process and finally the PHA production in an aerobic process (see also Figure 2). In contrast to $[11,12]$ the PHA production process described in this work is designed as a side stream process of a municipal WWTP and does not include the treatment of waste water. Therefore, the whole process can focus on polymer production only. 


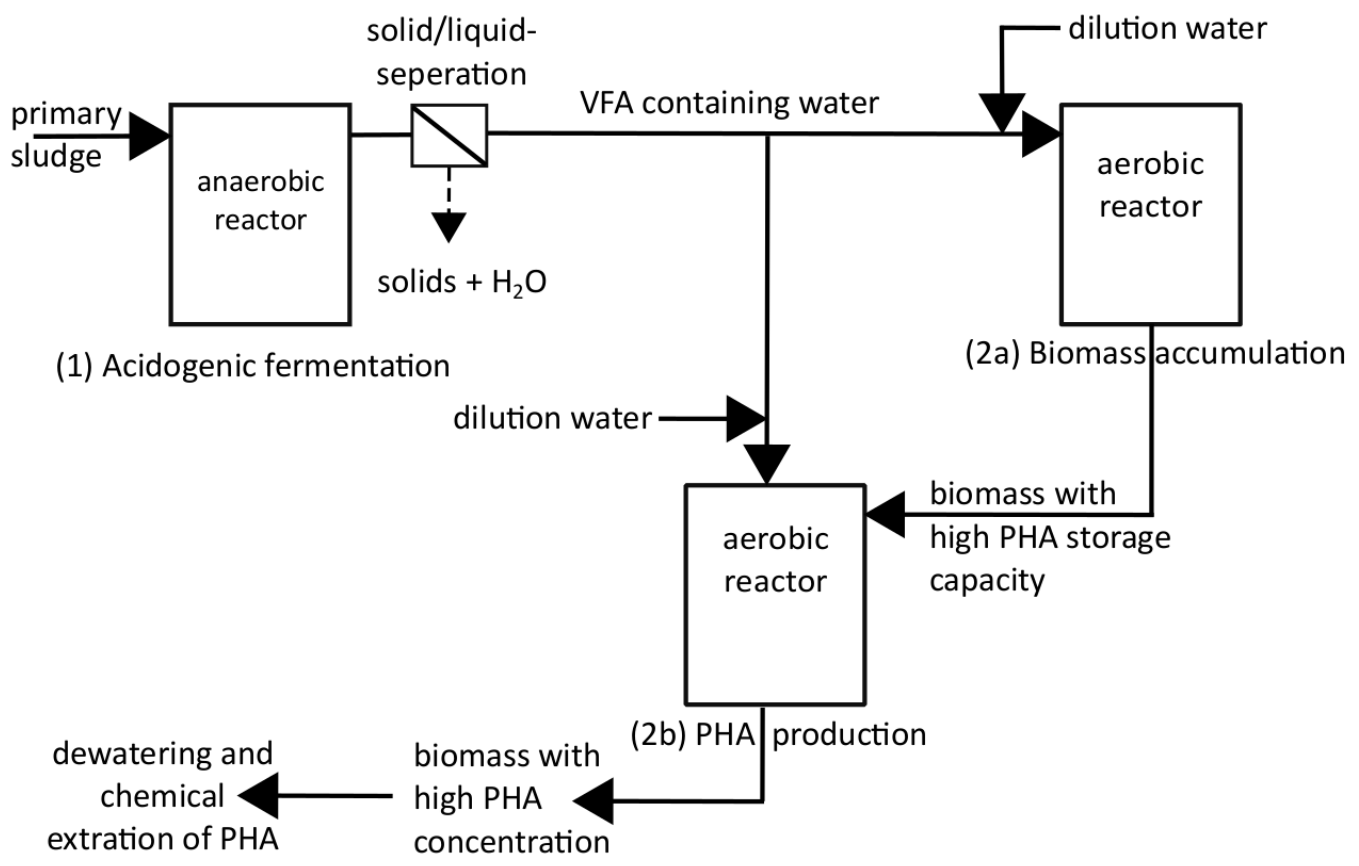

Figure 2. PHA production scheme.

The possibility to use ice-cream waste water as alternative source material for the VFA production was shown by [13] while [14] investigated the effect of $\mathrm{pH}$, sludge-retention time (RT) and acetate concentration on the PHA production from municipal waste water. Diverse authors [15-18] stated that there is a general possibility to produce PHA from activated sludge.

In many of the research projects on PHA production, synthetic waste water was used to gain knowledge about one part of the PHA production or the production's operating conditions [19-25]. However, so far no research group has investigated the general possibility and all operating conditions of a biopolymer production using only material flows of a WWTP.

PHA production itself is based on a bacteria mixed culture selection from excess sludge via aerobic dynamic feeding. The installed feast/famine regime for enrichment of PHA producing bacteria is state of the art and tested by many authors $[19,23,26,27]$. The feast-phase is defined as a period of substrate availability and could be monitored via the reactors oxygen concentration. During the period of starvation (famine-phase) bacteria with the ability of polymer-storage gained a selection advantage as they are able to use the stored polymers as carbon and energy source.

The objective of this research project was to find the most suitable raw material and all operating conditions for the VFA and PHA production process using only material flows of a WWTP. At first the suitability of different raw materials of a municipal WWTP for VFA-production were investigated and afterwards the influence of operating conditions (temperature, $\mathrm{pH}$, retention time (RT) and withdrawal (WD)) and reactor operation method. Another concern was, how the tested operating conditions or the diversity of the used material flows of a WWTP influence the VFA composition and the type of PHA produced. As there is a variation in the composition of the used material flows (different sludge) of a WWTP, it is of particular importance to observe their influence on VFA production and composition.

Then the possibility to produce PHA out of the VFA containing substrate was tested using a feast/famine regime (as shown in Figure 3). Subsequently, the influence of operating conditions (temperature, $\mathrm{pH}$, cycle time $(\mathrm{CT})$ and substrate concentration) on PHA production were investigated. 


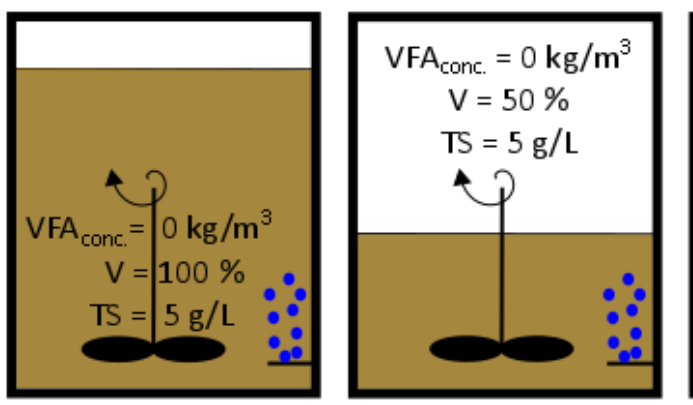

End of famine-phase
End of emptying process

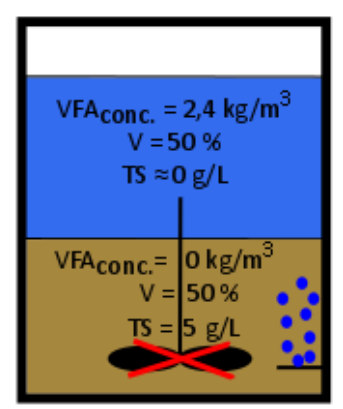

Refilling

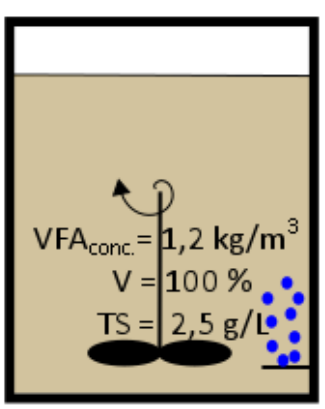

Begin of feast-phase

Figure 3. Emptying and refilling process during aerobic dynamic feeding (values shown are an example for investigated operation conditions), modified after [28].

The PHA potential on German WWTPs was calculated based on detailed data from operators of WWTPs [29] and the results of the PHA production experiments mentioned above. Finally, a profound estimation of the biopolymer potential of all WWTPs in the 28 member states of the European Union (EU) was made based on data provided by the EU [30] and the mentioned PHA production experiments.

\section{Materials and Methods}

\subsection{VFA Production}

\subsubsection{Conception of the Experiments}

For the VFA production ((1) Acidogenic fermentation in Figure 2) anaerobic reactors of different sizes $(4 \mathrm{~L}, 15 \mathrm{~L})$ were operated as batch reactors or as semi-continuous reactors. While the batch operation is defined as a one-time substrate filling at the beginning of the experiment with no withdrawal and refill during the test, a semi-continuously operation method allows to introduce and withdraw substrate to or from the reactor. Semi-continuously is defined as one-time substrate filling at the beginning of every cycle, e.g., daily within a test duration of one month.

All tests were conducted without sedimentation or biomass recirculation. Therefore, the hydraulic retention time equals the sludge age and both will be referred hereinafter as RT.

The raw material is the most important base for gaining high PHA production rates, so that the selection of suitable raw material has the number one priority. The improvement of the VFA production's operation conditions was examined afterwards with the most appropriate raw material found. A chronological test order was implemented as follows:

1. Selection of raw material

2. Investigation of the most suitable $\mathrm{pH}$-level

3. Evaluation of a retention time (RT) range

4. Selection of a suitable combination of RT and withdrawal (WD)

\subsubsection{Selection of Raw Material}

For raw material selection continuously stirred batch reactors with a volume of $4 \mathrm{~L}$ were used. Four different types of sludge, namely primary sludge (average total solid $\mathrm{TS}_{a}=43 \mathrm{~g} / \mathrm{L}$ ), excess sludge $\left(\mathrm{TS}_{\mathrm{a}}=10 \mathrm{~g} / \mathrm{L}\right)$, a one to one mixture of primary-and digested sludge $\left(\mathrm{TS}_{\mathrm{a}}=37.5 \mathrm{~g} / \mathrm{L}\right)$ and a one to one mixture of excess- and digested sludge $\left(\mathrm{TS}_{\mathrm{a}}=21 \mathrm{~g} / \mathrm{L}\right)$ from a municipal WWTP were treated under anaerobic conditions. Thereby the digested sludge from the WWTP's digester was only used as inoculum for the anaerobic process in order to find out, if it could accelerate the process. All types of sludge were investigated under four different conditions: $\mathrm{pH}$ controlled at $\mathrm{pH}=6$, without $\mathrm{pH}$-control 
and each at around $20^{\circ} \mathrm{C}$ or around $30^{\circ} \mathrm{C}$ reactor temperature. In summary 16 different tests were performed. The reactors were filled at the beginning of the experiments and samples of $50 \mathrm{~mL}$ were retrieved every day to determine the VFA concentration and composition. To achieve the selected temperature, the reactors were situated in temperature-controlled rooms. For $\mathrm{pH}$-controlled tests, the $\mathrm{pH}$-value was measured by a mobile $\mathrm{pH}$ meter (WTW $\mathrm{pH} 340 \mathrm{i}$ ) and adjusted with $\mathrm{NaOH}$ by hand twice a day. The test duration for all experiments was 18 days to 20 days. A sample of all tested types of sludge was taken before and after the tests to determine the chemical oxygen demand (COD), the total Kjeldahl nitrogen(TKN) and total P.

\subsubsection{Evaluation of Operating Conditions}

As the influence of fermentation temperature was already observed during the selection of the raw material, three additional operating conditions $(\mathrm{pH}, \mathrm{RT}, \mathrm{WD})$ were investigated in continuous stirred tank reactors (CSTR) with a volume of $15 \mathrm{~L}$. For all experiments primary sludge from a municipal WWTP was used as raw material and a sample was retrieved prior to the experiments to determine COD, TKN and total P. All reactors were placed in a temperature-controlled room at around $30^{\circ} \mathrm{C} . \mathrm{pH}$ was monitored at all times via a Metrom Profitrode $\mathrm{pH}$ probe and automatically adjusted with $\mathrm{NaOH}$ during all tests.

For the batch tests ( $\mathrm{pH}$, pre-RT) all reactors were filled with primary sludge at the beginning and samples of $100 \mathrm{~mL}$ were retrieved every day to determine the VFA concentration and composition. The batch test period was 18 days to 20 days long. Former studies show a high VFA production in a $\mathrm{pH}$-range between 5 [11] and 9 [31] or 11 [32]. In consequence a range of $\mathrm{pH}$-levels $(\mathrm{pH}=6,6.5,7,8$, 10) were tested.

For the semi-continuously operated tests all reactors were filled with primary sludge at the beginning and operated under $\mathrm{pH}$-controlled conditions at $\mathrm{pH}=6$. After a starting phase of 10 days, to accumulate VFAs, the semi-continuous operation phase began, for which a certain amount of the sludge in the reactor was exchanged. Samples of $100 \mathrm{~mL}$ were retrieved to analyse the VFA concentration and composition for about 40 days with a RT of 4 days, 6 days and 8 days, each with $25 \%$ and $50 \%$ WD. Additionally, a $75 \%$ WD was performed with a RT of 4 days. A RT of 2 days was also tested with a WD of 50\%. RT and WD are related factors, e.g., a RT of 4 days was used when $25 \%$ of the sludge was exchanged every day, $50 \%$ every second day or $75 \%$ every third day.

\subsubsection{Analytical Procedures}

COD, TKN, total $\mathrm{P}$ and total solids (TS) were determined according to standard methods.

The concentration and composition of volatile fatty acids, namely formate (Fo), acetate (Ac), propionate (Pro) and butyrate $(\mathrm{Bu})$, were detected by high performance liquid chromatography (HPLC). Therefore, the sample was acidified to $\mathrm{pH}=2$ and filtered through $0.45 \mu \mathrm{m}$ membrane filter. Afterwards HPLC detection was performed using a HP1100 chromatographer equipped with an UV detector and a Varian Metacarb $87 \mathrm{H}$ column. Sulphuric acid $(0.05 \mathrm{M})$ was used as eluent at a flow rate of $0.6 \mathrm{~mL} / \mathrm{min}$. The detection wavelength was $210 \mathrm{~nm}$. Volatile fatty acid's concentration was calibrated using $4 \mathrm{nmol}$ to $4000 \mathrm{nmol}$ standards.

As the results of formic acid detection was below detection point for all except one test, formic acid is not shown in the VFA composition.

\subsubsection{Conversion of Units}

For a better comparability all results regarding VFA concentrations, COD, TKN and total P were converted into $\mathrm{mg} / \mathrm{L}$.

The concentration of VFA in terms of $\mathrm{mg} / \mathrm{L}$ is defined as:

$$
\mathrm{VFA}=\mathrm{Ac}+\mathrm{Pro}+\mathrm{Bu}
$$


The degree of acidification (DA) was calculated according to [33] as shown in Equation (2). As VFA results are given in $\mathrm{mg}_{\mathrm{VFA}} / \mathrm{L}$ they have to be converted into COD units as shown in Equation (3)

$$
\mathrm{DA}=\mathrm{VFA} / \mathrm{COD}_{\mathrm{S}} \text { in }\left(\mathrm{mg}_{\mathrm{COD}} / \mathrm{L}\right) /\left(\mathrm{mg}_{\mathrm{COD}} / \mathrm{L}\right)
$$

with $\mathrm{COD}_{\mathrm{S}}=\mathrm{COD}$ of Substrate at the start.

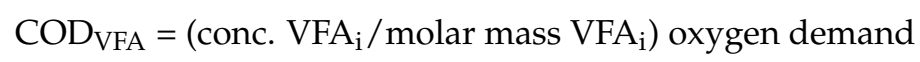

with $\mathrm{i}=\mathrm{Ac}$, Pro, Bu.

For a better comparability regarding the different $\mathrm{RT}$ and $\mathrm{WD}$, the average of the VFA concentration during the test period was calculated. In a second step, the average VFA concentration was used to calculate the average VFA production rate $\left(\mathrm{PR}_{\mathrm{VFA}}\right)$. This step also eliminates the reactors size and can hence be considered as average VFA production rate per day and litre, which will be referred to production rate (PR) hereinafter (Equation (4)).

$$
\mathrm{PR}_{\mathrm{VFA}}=\mathrm{av} . \mathrm{VFA} \text { conc. } / \mathrm{RT} \text { in } \mathrm{mg}_{\mathrm{VFA}} /(\mathrm{L} \times \text { day })
$$

This calculation helps to compare results from different reactor sizes and retention times.

\subsection{PHA Production}

\subsubsection{Experimental Set-Up}

The overall process describing the production of biopolymers from municipal waste water is displayed in Figure 2. For PHA production only "(2a): Biomass accumulation" and "(2b): PHA production" is considered. The first step, the volatile fatty acids (VFA) production, was already discussed in Chapter 2.1. The substrate produced in step 1 under anaerobic fermentation process at $30{ }^{\circ} \mathrm{C}, \mathrm{pH}=6, \mathrm{RT}=4$ days and a withdrawal of $25 \%$ was frozen at $-18^{\circ} \mathrm{C}$ and defrosted about $24 \mathrm{~h}$ prior to its use as input material for phase 2 PHA production.

During all PHA production tests continuous stirred tank reactor (CSTR) with a volume of $15 \mathrm{~L}$ were used. All reactors were equipped with a $\mathrm{pH}$ - and oxygen-probe. If necessary, $\mathrm{pH}$-value was adjusted via a dosing pump. $\mathrm{pH}$ levels were controlled by the $\mathrm{pH}$ probe and adjusted with $\mathrm{NaOH}$ or $\mathrm{H}_{2} \mathrm{SO}_{4}$. The reactor temperature was controlled via the $\mathrm{pH}$-probe and manually adjusted using a heating bath (Haake DC30) and a heat exchanger, installed in the reactor. To maintain aerobic conditions an aerator was installed in the reactor. All reactors were operated in batch mode. The batch operation is defined as a one-time substrate filling at the beginning of the aerobic dynamic feeding-cycle with no withdrawal and refill during the cycle. There was no sedimentation or biomass recirculation in all tests. Therefore, the hydraulic retention time equals the sludge age and both will be referred hereinafter as RT. At the end of every cycle 7.5 L were withdrawn from reactor $2 \mathrm{a}$ and filled into Reactor 2b. Hence a RT of 2 days was implemented. Afterwards both reactors were filled with $7.5 \mathrm{~L}$ of substrate and fresh water to achieve the working volume of $15 \mathrm{~L}$ per reactor. Reactor $2 \mathrm{~b}$ was emptied at the end of the feast-phase, and samples were taken to measure the PHA concentration and composition.

Both reactors were operated under similar conditions, just differing concerning nutrient availability. As the VFA enriched substrate showed nutrient limited conditions, with a Carbon:Nitrogen:Phosphorus (C:N:P)-ratio in a range of 100:2:0.5 to 100:3:0.8 [34] $\mathrm{CH}_{4} \mathrm{~N}_{2} \mathrm{O}$ and $\mathrm{KH}_{2} \mathrm{PO}_{4}$ were added to Reactor $2 \mathrm{a}$ to create optimal conditions for the bacteria growth $(\mathrm{C}: \mathrm{N}: \mathrm{P}=$ 100:5:1) and selection process. Reactor $2 b$, however, was operated under the named nutrient limited conditions to reach a higher PHA concentration.

Samples to determine the PHA concentration were taken at the end of the feast-phase. The total solid (TS) concentration was measured at the end of each cycle and was about $5 \pm 0.5 \mathrm{~g} / \mathrm{L}$ in both 
reactors. This was done to figure out if the selection process in Reactor $2 \mathrm{a}$ was working correctly or if the biomass concentration was decreasing e.g., for lack of nutrients. As the biomass concentration was stable throughout all experiments no further tests regarding cell growth were conducted.

Experiments regarding the substrate concentration and temperature selection had the top priority. Afterwards the optimisation of all other operation conditions concerning the PHA production was examined with the most appropriate reactor temperature and substrate concentration found. A chronological test order was implemented as follows:

1. Selection of a suitable substrate concentration

2. Investigation of the reactor temperature

3. Evaluation of a suitable $\mathrm{pH}-\mathrm{level}$

4. Selection of a suitable cycle time

\subsubsection{Investigation Concerning the Best Substrate Concentration}

As there is a big variation in substrate concentration in literature, different substrate concentration of $1200 \mathrm{mg}_{\mathrm{VFA}} / \mathrm{L}$ and $2000 \mathrm{mg}_{\mathrm{VFA}} / \mathrm{L}$ were tested at $20^{\circ} \mathrm{C}$ or $30^{\circ} \mathrm{C}, \mathrm{pH}=7$ or without $\mathrm{pH}$ control and a CT $=24 \mathrm{~h}$. The named concentrations were chosen to avoid possible problems triggered by substrate inhibition.

\subsubsection{Investigation Concerning the Best Temperature}

The temperatures of material flows from a municipal WWTP are about $15^{\circ} \mathrm{C}$ to $20^{\circ} \mathrm{C}$ in temperate climates and might exceed $30^{\circ} \mathrm{C}$ in hot climates or after mesophilic acidification. So tests with $15^{\circ} \mathrm{C}$, $20^{\circ} \mathrm{C}$ and $30^{\circ} \mathrm{C}$ were performed with a substrate concentration of $1200 \mathrm{mg}$ VFA $/ \mathrm{L}, \mathrm{pH}=7$ and a CT of $24 \mathrm{~h}$ or $48 \mathrm{~h}$ to find the best reactor temperature regarding PHA production. To avoid a substrate induced influence all tests were conducted with the same substrate batch.

\subsubsection{Investigation Concerning the Best $\mathrm{pH}$ Level}

As the best $\mathrm{pH}$ level to produce PHA depends on the used substrate, various $\mathrm{pH}$ levels $(6,7,8$, 9, without $\mathrm{pH}$ control) were tested in this study with a substrate concentration of $1200 \mathrm{mg}_{\mathrm{VFA}} / \mathrm{L}$, a temperature of $20^{\circ} \mathrm{C}$ and a CT $=24 \mathrm{~h}$.

\subsubsection{Investigation Concerning the Best Cycle Time}

To find the most suitable cycle time (CT) for the bacteria selection process, experiments with a substrate concentration of $1200 \mathrm{mg}_{\mathrm{VFA}} / \mathrm{L}$ were conducted at a temperature of $20^{\circ} \mathrm{C}$ and at $\mathrm{pH}=7$ or 8 . As the feast/famine ratio is more important than the overall CT a constant substrate concentration should ensure that the feast phases of the cycles were constant and the variation in CT resulted in a different famine phase, only. [25] stated that the feast-phase should not last longer than $20 \%$ of the overall CT to create a selection pressure on non-PHA accumulating bacteria. Therefore, CTs of $24 \mathrm{~h}$, $48 \mathrm{~h}$ and $72 \mathrm{~h}$ were tested.

\subsubsection{Analytical Procedures}

COD, TKN, total P and total solids (TS) were determined according to standard methods.

The concentration and composition of polyhydroxyalkanoates (PHA), namely polyhydroxybutyrate (PHB) and polyhydroxyvalerate (PHV), were detected by gas chromatography, according to [35] with some variations. Therefore, the biomass was separated via a centrifuge at $10,000 \mathrm{rpm}$ for $20 \mathrm{~min}$ and dried at $105^{\circ} \mathrm{C}$. Afterwards the sample was pulverised with a ball mill and about $100 \mathrm{mg}$ were digested and analysed. Detection was performed using a Perkin Elmer Autosystem XL chromatographer and a VF5ms $30 \mathrm{~m} \times 0.25$ column. Helium was used as carrier gas. PHA concentration was calibrated using $4 \mathrm{~mL}$ standards. The concentration and composition 
of volatile fatty acids, namely formate (Fo), acetate (Ac), propionate (Pro) and butyrate (Bu), were detected as described in Chapter 2.1.3.

\subsubsection{Calculation of Parameters}

For better comparability, all results regarding VFA concentrations, COD, TKN and total P were converted into $\mathrm{mg} / \mathrm{L}$. The concentration of PHA in terms of $\%$ cell dry weight (CDW) is defined as:

$$
\mathrm{PHA}=\mathrm{PHB}+\mathrm{PHV}
$$

\subsection{Potential Analysis}

\section{Calculations}

Based on the PHA production results described in Chapter 3, a potential analysis was performed. The aim of the analysis was to determine the potential of biopolymer production (based on renewal resources and biodegradable, see definition in Chapter 1) on German and European waste water treatment plants (WWTP) by using sewage sludge as a substrate. All input data used for the calculations can be found in Table 1 .

A plausibility analyses was performed to cross-check the most important input data like the amount of primary sludge (PS) per population equivalent (PE).

As detailed data about waste water and sewage sludge production are available in Germany, the first step of the potential analysis was calculated using these data together with results presented in Chapter 3. In a second calculation step, data provided by the European Union (EU) were used to create an in-depth estimation of the biopolymer potential considering all 28 member states.

Table 1. Input data used during the potential analysis.

\begin{tabular}{|c|c|c|c|}
\hline Parameter & Unit & Value & Literature \\
\hline Connected people equivalents (PE) on German WWTPs & Mio. PE & 115.7 & [29] \\
\hline Proportion of PSP *-PEs regarding total PEs in Germany & $\%$ & 92 & [29] \\
\hline PEs with PSP * in Germany & Mio. PE & 106.56 & \\
\hline Amount of primary sludge per PE & $\mathrm{L} /(\mathrm{PE} \times \mathrm{d})$ & 1.1 & [36] \\
\hline Total solid conc. of primary sludge/acidified material & $\mathrm{g} / \mathrm{L}$ & 35 & [4] \\
\hline VFA concentration & $\mathrm{g}_{\mathrm{VFA}} / \mathrm{m}^{3}$ & 7,653 & [4] \\
\hline Retention time and withdrawal at the first production step & $\mathrm{d} ; \% / \mathrm{d}$ & $4 ; 25$ & [4] \\
\hline Total solid concentration in the aerobic Reactors $2 a / 2 b$ & $\mathrm{~g} / \mathrm{L}$ & 5.0 & [4] \\
\hline Loading rate for PHA production & $\mathrm{kg}$ VFA $/ \mathrm{m}^{3}$ & 1.2 & [4] \\
\hline Retention time and withdrawal at Reactor $2 a$ & $\mathrm{~d}$ and $\% / \mathrm{d}$ & 2 and 50 & [4] \\
\hline PHA proportion based on cell dry weight & CDW.-\% & 28.4 & [36] \\
\hline Yearly sewage sludge amount in the EU & $\mathrm{t}_{\mathrm{TS}} / \mathrm{a}$ & $13,245,180$ & [30] \\
\hline Yearly sewage sludge amount in Germany & $\mathrm{t}_{\mathrm{TS}} / \mathrm{a}$ & $1,815,150$ & [30] \\
\hline
\end{tabular}

\section{Results and Discussion}

\subsection{VFA Production}

\subsubsection{Potential Analysis}

Table 2 displays the results of the performed investigations ordered by degree of acidification. Primary sludge performed best under three out of four conditions and yielded by far the best degree of acidification (DA) with $31 \%$ at $30{ }^{\circ} \mathrm{C}$ under $\mathrm{pH}$-controlled conditions [34]. The second best carbon source, a one to one mixture of primary and digested sludge at $20^{\circ} \mathrm{C}$ under $\mathrm{pH}$-uncontrolled conditions, achieved only a DA of $14 \%$. In five out of eight experiments $\mathrm{pH}$-uncontrolled conditions resulted in a higher DA. Therefore, a fermentation without $\mathrm{pH}$ control should be considered for all fermentation 
raw materials. However, primary sludge yielded better DAs with $\mathrm{pH}$ control at both investigated temperatures. At $30^{\circ} \mathrm{C}$ the DA of primary sludge was twice as high than without $\mathrm{pH}$ control.

Table 2. Degree of acidification and VFA composition in dependence of substrate and operation conditions (batch-tests, $4 \mathrm{~L}$ ).

\begin{tabular}{cccccc}
\hline Carbon Source & $\mathbf{p H}$ & Temperature & Max. Conc. & DA & Ac/Pro/Bu \\
\hline Primary sludge & & $\left.\mathbf{~}^{\circ} \mathbf{C}\right)$ & $\mathbf{( D a y )}$ & $\mathbf{( \% )}$ & $\mathbf{( \% )}$ \\
\hline Primary sludge & $6^{*}$ & 30 & 9 & 31 & $52 / 48 / 0$ \\
Primary sludge & $6^{*}$ & 20 & 7 & 14 & $56 / 44 / 0$ \\
Primary-/digested sludge & 4.6 & 30 & 10 & 14 & $41 / 59 / 0$ \\
Primary sludge & 7 & 20 & 14 & 14 & $79 / 21 / 0$ \\
Primary-/digested sludge & 4.5 & 20 & 15 & 13 & $42 / 58 / 0$ \\
Excess sludge & 7.5 & 30 & 14 & 12 & $84 / 16 / 0$ \\
Excess sludge & 7 & 30 & 5 & 10 & $59 / 20 / 20$ \\
Primary-/digested sludge & 6.5 & 20 & 4 & 8 & $60 / 20 / 20$ \\
Excess sludge & $6^{*}$ & 30 & 5 & 7 & $75 / 25 / 0$ \\
Excess sludge & $6^{*}$ & 20 & 7 & 6 & $24 / 76 / 7$ \\
Primary-/digested sludge & $6^{*}$ & 30 & 5 & 6 & $67 / 33 / 0$ \\
Excess-/digested sludge & $6^{*}$ & 20 & 2 & 3 & $57 / 43 / 0$ \\
Excess-/digested sludge & 8 & 30 & 4 & 3 & $100 / 0 / 0$ \\
Excess-/digested sludge & 7.5 & 30 & 3 & 3 & $76 / 0 / 24$ \\
Excess-/digested sludge & $6^{*}$ & 20 & 7 & 2 & $100 / 0 / 0$ \\
\hline
\end{tabular}

${ }^{*}$ Marks conditions $\mathrm{pH}$-controlled.

Table 2 also shows the composition of the VFA. The results varied strongly between $24 / 76 / 7$ (\%Ac/\%Pro/\%Bu) and 100/0/0 depending on the used raw material. Primary sludge produced none butyric acid and acetic and propionic acid in nearly two equal sections. Excess sludge on the other hand produced up to $21 \%$ butyric acid, while the one to one mixture of primary and digested sludge produced the most acetic acid (up to $84 \%$ ) of all tested raw materials. The results show that the raw material has a major influence on the VFA composition.

As the use of primary sludge resulted in highest DA and showed only small variations in VFA composition under the tested conditions, it was chosen as raw material and used in all further tests.

Beside the ability to produce VFAs, primary sludge has other advantages as raw material for the PHA production. As primary sludge is a mixture of organic material, water and fermenting microorganisms no longsome biological adaptation-phase or biomass recirculation for the fermentation process was necessary. During all experiments primary sludge showed nutrient limited conditions, as described in Chapter 2.2.1. This is of particular significance given that nutrient limited conditions are essential for the later PHA production [19,37].

\subsubsection{Temperature}

The aim of the investigations at two temperature levels was to ascertain if the VFA production at ambient temperature $\left(20^{\circ} \mathrm{C}\right)$ can reach the same VFA production compared with heating the sludge.

In six out of eight tested combinations a temperature increase from 20 to $30^{\circ} \mathrm{C}$ caused a higher VFA production as shown in Table 2. The experiment confirmed the results of [32], who stated that the VFA concentration increases with higher fermentation temperature. Using primary sludge as raw material (under $\mathrm{pH}$-controlled conditions) the temperature change from 20 to $30^{\circ} \mathrm{C}$ caused a DA increase from $14 \%$ to $31 \%$.

The general assumption that the acidification rate is higher at $30{ }^{\circ} \mathrm{C}$ than at $20{ }^{\circ} \mathrm{C}$ could not be confirmed. Only three out of eight tested combinations reached their VFA maximum at $30{ }^{\circ} \mathrm{C}$ in a shorter span of time than at $20^{\circ} \mathrm{C}$. Four out of them even reached their VFA maximum at $20{ }^{\circ} \mathrm{C}$ in a shorter span of time than at $30^{\circ} \mathrm{C}$. The results can be seen in Table 2. Primary sludge under 
$\mathrm{pH}$-controlled conditions obtained its VFA maximum after 7 days at $20^{\circ} \mathrm{C}$ and after 9 days at $30^{\circ} \mathrm{C}$. Nevertheless, the fact that the DA of primary sludge under $\mathrm{pH}$-controlled conditions at $30^{\circ} \mathrm{C}$ was twice as high as the DA at $20^{\circ} \mathrm{C}$ is all the more important as the VFA production at $30^{\circ} \mathrm{C}$ lasted only about $30 \%$ longer.

The variation of temperature has a wide range of influence on the VFA composition, depending on the used substrate. As primary sludge was already chosen as substrate for the optimisation tests, only its VFA composition was of interest for further tests. However, in the case of primary sludge the temperature change investigated resulted only in marginal changes in the VFA composition.

Consequently, a temperature around $30{ }^{\circ} \mathrm{C}$ for the further experiments was considered as reasonable.

\subsection{3. $\mathrm{pH}$}

As illustrated in Figure 4, no big difference in the maximum VFA concentration between $\mathrm{pH}=6$ and $\mathrm{pH}=8$ was observed. A $\mathrm{pH}$ value of 7 yielded the highest result with $18,286 \mathrm{mg}_{\mathrm{VFA}} / \mathrm{L}$ after a RT of 10 days. The fermentation at $\mathrm{pH}=10$ reached significantly worse results with a maximum of 10,050 $\mathrm{mg}_{\mathrm{VFA}} / \mathrm{L}$ only at 18 days retention time. This is in contrast to the results of [31] showing the best result at $\mathrm{pH}=9$ with excess sludge and food waste as source material and [32] yielding the highest result at $\mathrm{pH}=11$ with excess sludge as raw material.

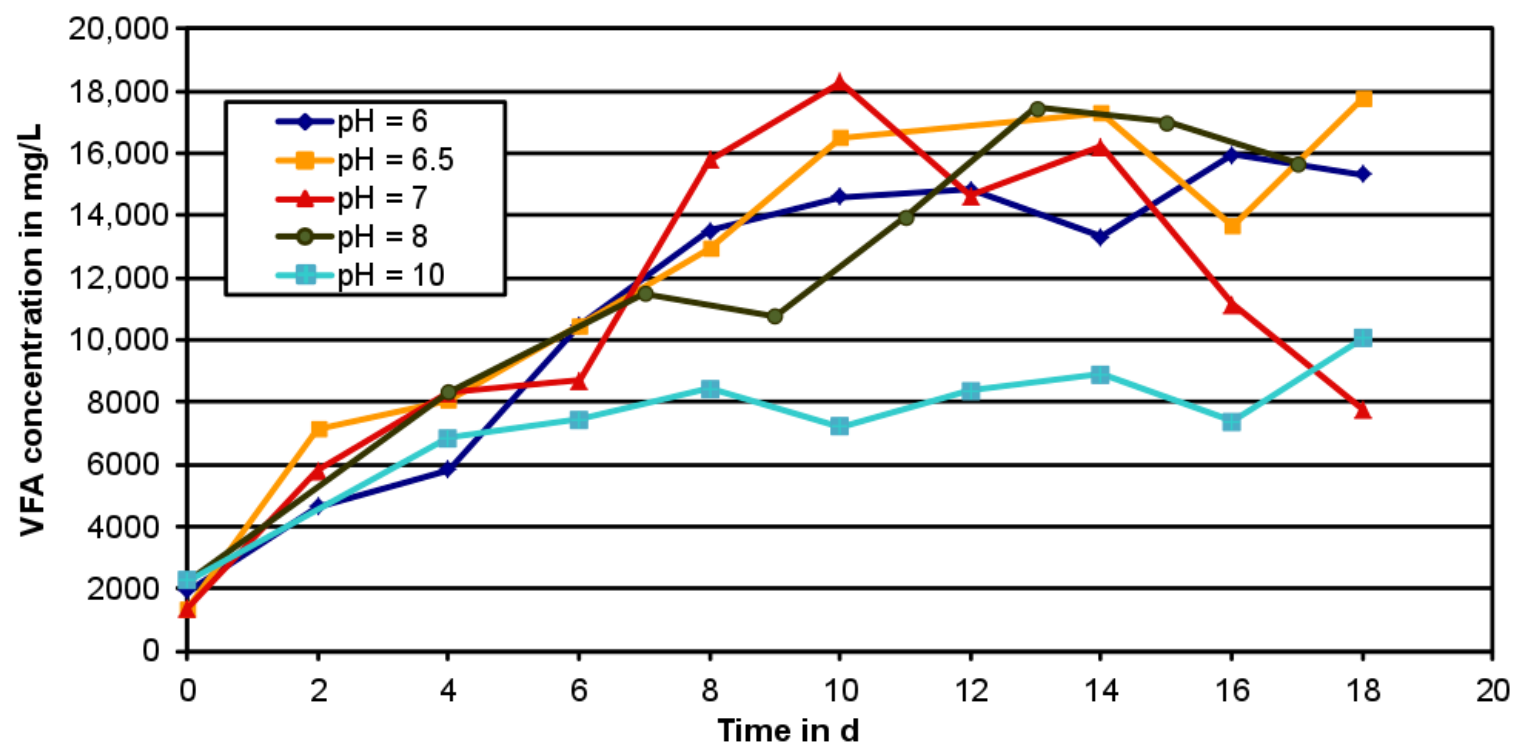

Figure 4. VFA concentrations during tests at different $\mathrm{pH}$ levels.

Although $\mathrm{pH}=7$ yielded the best result, methane production turned out to be an issue at this pH-value. After about 15 days the acetate concentration was falling rapidly and the overall VFA concentration after 18 days was less than $44 \%$ of the maximum (Figure 4 ). During this period more than $15 \mathrm{Vol} . \%$ methane was detected in the reactor via gas measurement. To prevent methanogenic conditions a pH-level of 6 has to be kept [38]. Consequently, further investigations were performed under $\mathrm{pH}=6$, although it produced about $12 \%$ less VFA within the batch experiments.

The variation of $\mathrm{pH}$-level showed a strong influence on the VFA composition. Changing the $\mathrm{pH}$ from 6 to 7 within the batch experiments caused a constant decrease in the acetic acid ratio as shown in Table 3. In the same tests, the propionic acid ratio increased, while the butyric acid ratio decreased to zero. At $\mathrm{pH}=8$ conditions a reverse trend was observed. With $60 \%$ the maximum acetic acid ratio as well as the minimum propionic acid ratio $(37 \%)$ was detected, while butyric acid was produced in small amounts $(3 \%)$. In comparison to $\mathrm{pH}=8$, a reduction of acetic acid and propionic acid production was detected at the highest tested $\mathrm{pH}$-level $(\mathrm{pH}=10)$, while the butyric acid ratio increased to the 
highest level ( $8 \%)$ observed. In contrast to the other $\mathrm{pH}$-values tested, formic acid was produced at $\mathrm{pH}$ $=10$ with a ratio of 16 .

Table 3. VFA composition and DA in dependence of $\mathrm{pH}$ or RT and WD.

\begin{tabular}{ccccccc}
\hline & Batch & \multicolumn{5}{c}{ Semi Continuous } \\
\hline $\mathbf{p H}$ & $\mathbf{A c / P r o} / \mathbf{B u}$ & $\mathbf{D A}$ & $\mathbf{p H}$ & $\mathbf{R T}$ and WD & Ac/Pro/Bu & $\mathbf{D A}$ \\
\hline & $\mathbf{( \% )}$ & $\mathbf{( \% )}$ & & $\mathbf{( d a y}$ and $\%)$ & $\mathbf{( \% )}$ & $\mathbf{( \% )}$ \\
\hline 6 & $45 / 51 / 4$ & 29 & 6 & 4 and 25 & $49 / 38 / 13$ & 15 \\
6.5 & $37 / 61 / 2$ & 29 & 6 & 4 and 50 & $46 / 47 / 7$ & 14 \\
7 & $28 / 72 / 0$ & 39 & 6 & 4 and 75 & $48 / 45 / 7$ & 14 \\
8 & $60 / 37 / 3$ & 29 & 6 & 6 and 25 & $51 / 38 / 11$ & 22 \\
10 & $45 / 31 / 8^{*}$ & 14 & 6 & 6 and 50 & $46 / 48 / 6$ & 17 \\
& & & 6 & 8 and 25 & $46 / 41 / 13$ & 20 \\
& & & 6 & 8 and 50 & $43 / 49 / 8$ & 19 \\
\hline
\end{tabular}

* Missing to $100 \%$ is formate.

\subsubsection{RT and WD}

To get an idea about how much adapted bacteria are needed in the reactor to produce the most VFAs a wide range of RT and WD was tested. $\mathrm{RT}=2$ days and $\mathrm{WD}=50 \%$ yielded poor results $\left(\mathrm{VFA}_{\max }\right.$ $<2000 \mathrm{mg}_{\mathrm{VFA}} / \mathrm{L}$ ) and after 10 days of semi-continuous operation the test was shut down. Therefore, these results are not shown. Further results ranged in a broad band between $5000 \mathrm{mg} \mathrm{VFA}_{\mathrm{f}} / \mathrm{L}$ and $10,000 \mathrm{mg}_{\mathrm{VFA}} / \mathrm{L}$.

Obviously, the VFA production with short RTs and small WDs fluctuated less than using long RTs and large WDs, what can be explained by the changing composition of the introduced primary sludge. These changes of the used primary sludge are mostly due to weather events. A rainfall after a period of dry weather can transport a huge amount of organic matter to the WWTP. Daily changes in the waste water's composition or different contents during the week could be another reason for changing the primary sludge's composition. Smaller WD stabilises the fermentation process because only little material is turned over and the reactor is less sensitive to heterogeneous primary sludge input.

Figure 5 shows the average VFA concentration over a period of 40 days for all investigated combinations. Both, RT and WD influenced the VFA production. With higher WD the VFA concentration was decreasing at all tested RTs. The highest overall VFA concentration was reached at a RT of 6 days with a WD of $25 \%$. Longer and shorter RTs (with a WD of $25 \%$, too) resulted in lower VFA concentrations.

In order to have a high PHA-production in the second stage the VFA production rate (PR) is more important than the VFA concentration, which could, if it exceeds a certain value, lead to a substrate inhibition [23]. Therefore, the PR was calculated on Equation (4). A RT $=4$ days and $\mathrm{WD}=25 \%$ yielded the top production rate with $\mathrm{PR}=1913 \mathrm{mg}_{\mathrm{VFA}} /(\mathrm{L} \times \mathrm{d})$ at a VFA concentration of $7653 \mathrm{mg}_{\mathrm{VFA}} / \mathrm{L}$ on average [4].

The variation of RT influenced the VFA composition only slightly as shown in Table 3. Acetic acid and propionic acid were produced in a similar range, while butyric acid was always the smallest part. Nevertheless, the variation of WD had an effect. With a WD of $25 \%$ the fraction of propionic acid was about $20 \%$ smaller throughout all tests, compared to a WD of $50 \%$ and $75 \%$, while the butyric acid ratio was nearly twice as much. The acetic acid ratio with a WD of $25 \%$ was slightly higher than for any other WDs.

As a stable VFA composition is necessary for high quality PHA production the possible fluctuation of the VFA composition during the whole test period is important. Figure 6 is exemplary for all semi-continuously operated tests and shows the concentrations of acetate, propionate and butyrate at $\mathrm{RT}=4$ days, $\mathrm{WD}=50 \%$ during the whole test period of 44 days. After a starting phase of 10 days 
(not shown in the figure) the semi-continuous operation began. Due to the change in the operation method (from batch to semi-continuously) a transition phase with a decrease in VFA concentration was observed for the first six days of semi-continuous operation. Fluctuations in the VFA concentration between day six and day 44 were due to the changing concentration and composition of the introduced primary sludge. Although a fluctuation in VFA concentration after the fermentation step was observed, only small changes in the VFA composition were detected. Thus, it was possible to show that the variability of the raw material primary sludge did not affect the VFA composition significantly.

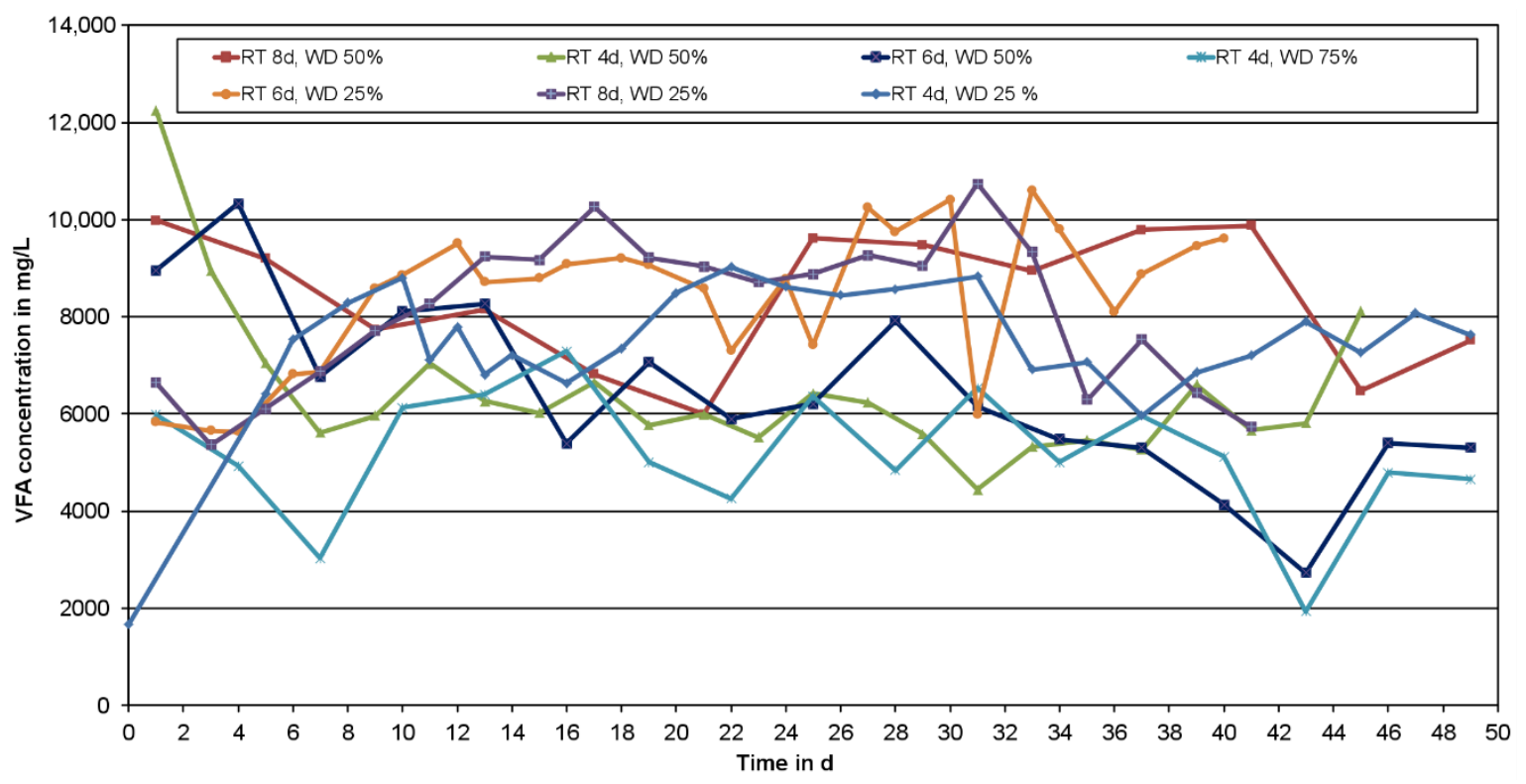

Figure 5. VFA concentration in dependence of RT and WD.

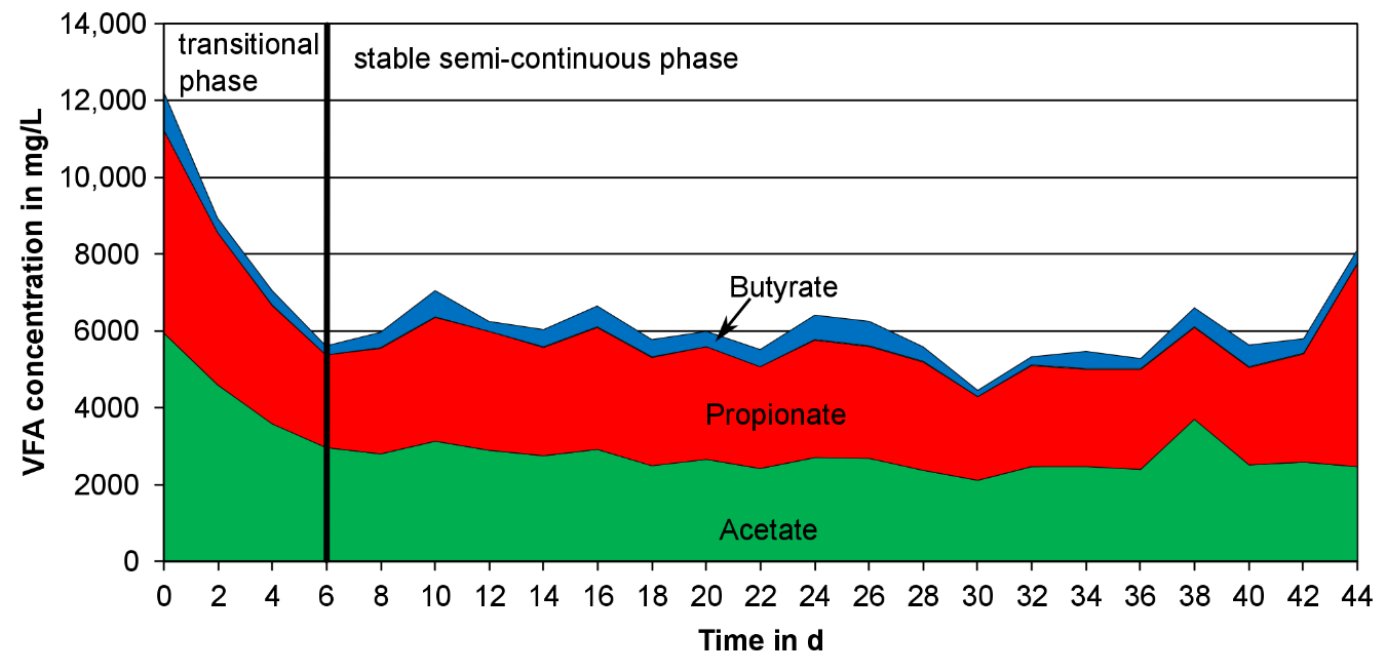

Figure 6. Development of the VFA concentration and composition at RT $=4$ days, $\mathrm{WD}=50 \%$.

\subsection{PHA Production}

The acidified primary sludge from phase 1 was used for the production of PHA in step two where the influence of different operating conditions was investigated. 


\subsubsection{Substrate Concentration}

The results of the conducted experiments are displayed in Table 4. It appears that higher PHA concentrations were gained at the lower substrate concentration tested. The maximum PHA concentration of $25.9 \%$ based on cell dry weight (CDW) was reached at a $\mathrm{pH}$ of 7 and a reactor temperature of $20^{\circ} \mathrm{C}$. With a VFA concentration of $2000 \mathrm{mg} / \mathrm{L}$ and a reactor temperature of $20{ }^{\circ} \mathrm{C}$ the highest PHA concentration achieved was $4.8 \% \mathrm{CDW}$, only and therefore much less than at a substrate concentration of $1200 \mathrm{mg} / \mathrm{L}$ at the same temperature. This confirms the observations of $[8,23,39]$ that an increasing substrate concentration could result in a substrate inhibition.

Table 4. PHA production in dependence of two tested substrate concentrations.

\begin{tabular}{ccccc}
\hline Substrate Conc. & Temp. & pH & PHA & PHB/PHV \\
\hline$\left(\mathbf{m g}_{\text {VFA }} / \mathbf{L}\right)$ & $\left({ }^{\circ} \mathbf{C}\right)$ & & $\mathbf{( \% ~ C D W ) ~}$ & (\% CDW/\% CDW) \\
\hline 1200 & 20 & $*$ & 13.2 & $7.0 / 6.2$ \\
1200 & 20 & 7 & 25.9 & $13.2 / 12.7$ \\
1200 & 30 & $*$ & 3.4 & $2.3 / 1.1$ \\
2000 & 20 & $*$ & 4.8 & $3.3 / 1.5$ \\
2000 & 20 & 7 & 1.8 & $<2 / 1.8$ \\
2000 & 30 & $*$ & 5.8 & $3.8 / 2.0$ \\
\hline
\end{tabular}

* Marks conditions without $\mathrm{pH}$-control.

Furthermore, the experiment at the higher temperature and the lower substrate concentration $\left(30{ }^{\circ} \mathrm{C}, 1200 \mathrm{mg} / \mathrm{L}\right)$ leads to a significant lower PHA production than at $20^{\circ} \mathrm{C}$ and $1200 \mathrm{mg} / \mathrm{L}$. This indicates that a reactor temperature of $20^{\circ} \mathrm{C}$ may be preferable for a primary sludge based PHA production (see also Chapter 3.2.2).

PHA composition did not show any dependence regarding to substrate concentration. During all tests higher proportions of PHB than PHV were produced. About twice as much PHB (than PHV) was produced at all experiments at a substrate concentration of $2000 \mathrm{mg} / \mathrm{L}$ and at $30^{\circ} \mathrm{C}$ with $1200 \mathrm{mg} / \mathrm{L}$, while a nearly equal proportion of both PHAs was reached at $1200 \mathrm{mg} / \mathrm{L}$ and $20^{\circ} \mathrm{C}$.

\subsubsection{Temperature}

Table 5 displays the results of the PHA production at different temperatures. As the bacteria metabolism is slower at lower temperatures a very long feast-phase was observed at $15^{\circ} \mathrm{C}$. To ensure a sufficiently long famine-phase the cycle time of $24 \mathrm{~h}$ was doubled at all test with a reactor temperature of $15^{\circ} \mathrm{C}$. Figure 7 shows the length of the feast-phase based on the reactors oxygen concentrations. The very long feast-phase at $15^{\circ} \mathrm{C}$ (around $22 \mathrm{~h}$ ) is clearly visible. All other feast-phases at $20^{\circ} \mathrm{C}$ or $30^{\circ} \mathrm{C}$ were significantly shorter and not longer than $600 \mathrm{~min}$. A somewhat surprising fact was that a faster bacteria metabolism at $30^{\circ} \mathrm{C}$ did not result in a shorter feast-phase than at $20^{\circ} \mathrm{C}$. These observations are in contrast to [40], who stated that shorter fest-phases are observed at higher temperatures. At the same time, they confirm the results of [41], who gained the highest PHA concentration at reactor temperatures around $20^{\circ} \mathrm{C}$. This effect may origin in the fact, that the used sewage sludge was already adopted to temperature around $20^{\circ} \mathrm{C}$. 
Table 5. PHA production in dependence of the reactor temperature.

\begin{tabular}{ccccc}
\hline Temp. & $\mathbf{p H}$ & $\mathbf{C T}$ & PHA & PHB/PHV \\
\hline$\left({ }^{\circ} \mathbf{C}\right)$ & & $\mathbf{( h )}$ & $\mathbf{( \% ~ C D W )}$ & $\mathbf{( \% ) ~ C D W / \% ~ C D W ) ~}$ \\
\hline 15 & 7 & $24 / 48$ & 4.2 & $2.5 / 1.7$ \\
15 & 8 & $24 / 48$ & 3.9 & $2.5 / 1.4$ \\
20 & 7 & 24 & 25.9 & $13.2 / 12.7$ \\
20 & $*$ & 24 & 13.2 & $7.0 / 6.2$ \\
30 & 7 & 24 & 0.6 & $<2 / 0.6$ \\
30 & $*$ & 24 & 3.4 & $2.3 / 1.1$ \\
\hline
\end{tabular}

${ }^{*}$ Marks conditions without $\mathrm{pH}-$ control.

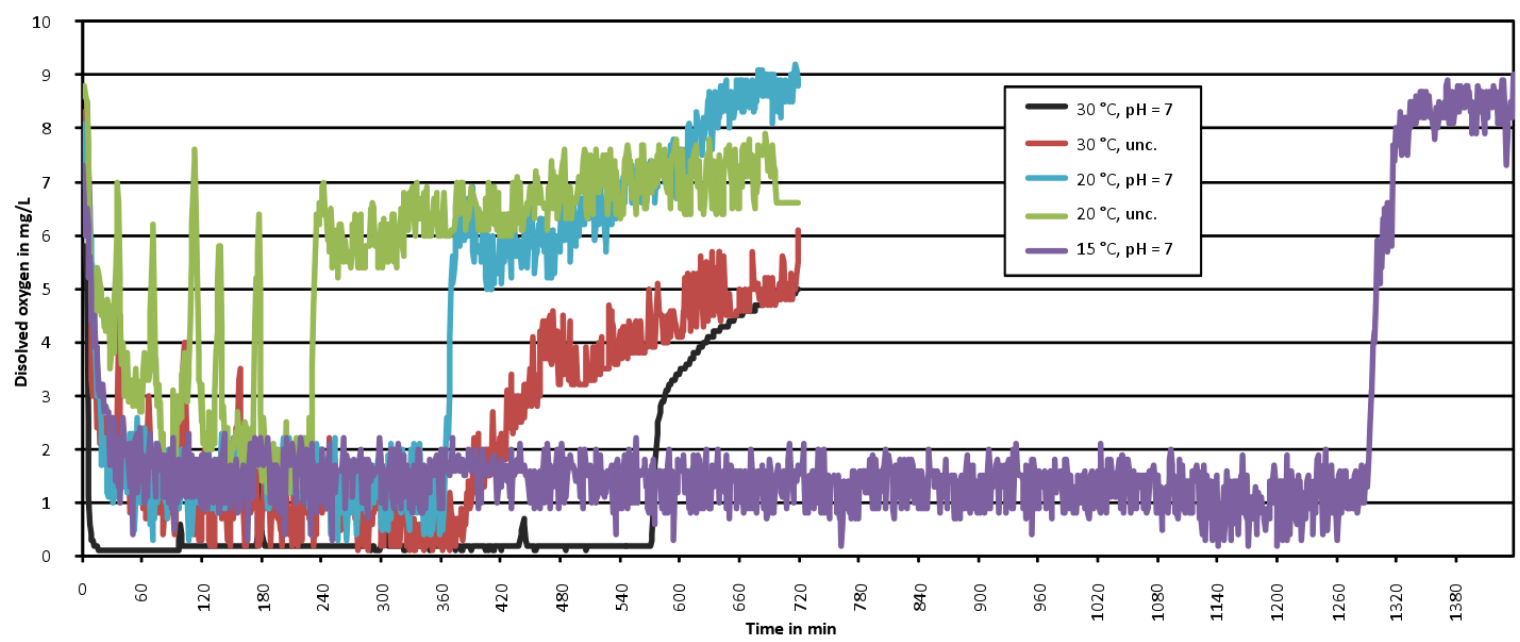

Figure 7. Reactor temperature influence on the feast/famine phase length.

There is no influence on PHA composition due to temperature changes. The results of Chapter 3.2.1 that the PHB/PHV ratio is about $2 / 1$ at lower PHA concentrations produced, was confirmed (Table 5 at $15^{\circ} \mathrm{C}$ and $30^{\circ} \mathrm{C}$ ), while both proportion are more or less equal at a higher PHA production (Table 5 at $20^{\circ} \mathrm{C}$ ).

As listed in Table 5 conditions of $20{ }^{\circ} \mathrm{C}$ yielded the highest PHA concentrations with $13.2 \% \mathrm{CDW}$ and $25.9 \% \mathrm{CDW}$. At a reactor temperature of $15{ }^{\circ} \mathrm{C}$ or $30^{\circ} \mathrm{C}$ a maximum PHA concentration of less than $4.5 \% \mathrm{CDW}$ was reached, only. In consequence further experiments were conducted at $20^{\circ} \mathrm{C}$ to achieve the best possible PHA concentration [42].

\subsection{3. $\mathrm{pH}$}

Table 6 illustrates big differences in the maximum PHA concentration between the tested $\mathrm{pH}$ levels. All tests were operated in batch-mode with a cycle time of one day. The substrate's $\mathrm{pH}$ was adjusted before adding it into the reactor. An exception was the $\mathrm{pH}$ uncontrolled test. This experiment should clarify if a high PHA production is possible at fluctuating $\mathrm{pH}$ value. During the whole cycle the $\mathrm{pH}$ varied between 7.3 at the beginning of the feast-phase and 9.3 at the end of the famine-phase, with an average $\mathrm{pH}$ around 9. 
Table 6. PHA production in dependence of the $\mathrm{pH}$.

\begin{tabular}{ccc}
\hline \multirow{2}{*}{$\mathbf{H}$} & PHA & PHB/PHV \\
\cline { 2 - 3 } & $\mathbf{( \% \mathbf { C D W } )}$ & $\mathbf{( \% \mathbf { C D W } / \mathbf { C D W } )}$ \\
\hline unc. (av. 9) & 13.2 & $7.0 / 6.2$ \\
6 & - & - \\
7 & 25.9 & $13.2 / 12.7$ \\
8 & 28.4 & $14.7 / 13.7$ \\
9 & 4.4 & $3.0 / 1.4$ \\
\hline
\end{tabular}

The experiments with controlled $\mathrm{pH}$ values showed highly varying results. While there was no detectable PHA production at $\mathrm{pH}=6$, more than $25 \% \mathrm{CDW}$ was produced between $\mathrm{pH} 7$ and 8 , with a maximum PHA production of $28.4 \% \mathrm{CDW}$ at $\mathrm{pH}=8$. Then again, at the highest $\mathrm{pH}$ of 9 a low $\mathrm{PHA}$ production of $4.4 \%$ was reached only. The experiment without $\mathrm{pH}$ control produced around half as much PHA as the tests at $\mathrm{pH} 7$ or 8 . Nevertheless the results of the uncontrolled test were far better than at the same $\mathrm{pH}$-level of 9 during the controlled test. Still a $\mathrm{pH}$ controlled PHA production is preferable, as the maximum PHA production was obtained at $\mathrm{pH}$ controlled operation [42].

$\mathrm{pH}$ changes did not influence the PHA composition. As described in Sections 3.2.2 and 3.2.3 the $\mathrm{PHB} / \mathrm{PHV}$ ratio is $2 / 1$ at low PHA concentrations and nearly $1 / 1$ at a higher PHA production.

\subsubsection{Cycle Time}

When using a PHA production based on a bacteria mixed culture a feast/famine regime is crucial. This is the only way for PHA producing bacteria to gain a significant selection advantage over other microorganisms.

The produced amount of PHA in dependence of the length of the feast/famine-phase is displayed in Table 7. A correlation between the cycle time (CT) and the length of the feast-phase was observed, showing that a longer $\mathrm{CT}$ leads to a shorter feast-phase. This could be due to a longer and therefore harder famine-phase leading to a long period of starvation. It seems that after a bigger starvation, the bacteria's substrate uptake is higher and faster than at shorter cycle times. [39] highlights the cycle time must be such that the complete PHA is metabolised at the end of the famine-phase. This guideline was confirmed by testing samples, taken at the end of each famine-phase. No PHA was detected and therefore the required operating condition was kept during all tests. Thus, a cycle time of $24 \mathrm{~h}$ is sufficient.

Table 7. PHA production in dependence of the cycle time.

\begin{tabular}{ccccc}
\hline CT & Feast/Famine & Feast/Famine-Ratio & PHA & PHB/PHV \\
\hline $\mathbf{( h )}$ & $\mathbf{( m i n )}$ & $\mathbf{( \% / \% )}$ & $\mathbf{( \% ~ C D W )}$ & $\mathbf{( \% ~ C D W / \% ~ C D W ) ~}$ \\
\hline 24 & $524 / 916$ & $36 / 64$ & 28.4 & $14.7 / 13.7$ \\
48 & $500 / 2380$ & $17 / 83$ & 18.3 & $8.0 / 10.3$ \\
72 & $448 / 3872$ & $10 / 90$ & 21.4 & $8.3 / 13.1$ \\
\hline
\end{tabular}

A former study concluded that the proportion of the feast-phase should not exceed $20 \%$ of the CT, because a longer famine phase could lead to a lower selection pressure on non-PHA accumulating bacteria [26]. Table 7 shows a feast-phase proportion of $36 \%$ at a cycle time of $24 \mathrm{~h}$ and therefore nearly twice as high as suggested by [26]. Regardless, at this cycle time the highest PHA concentration (28.4\% CDW) was reached. A feast-phase proportion of $17 \%$ at a CT of $48 \mathrm{~h}$ led to a PHA production of $18.3 \%$ $\mathrm{CDW}$, while at the longest tested CT of $72 \mathrm{~h}$ a PHA production of $21.4 \% \mathrm{CDW}$ was observed with a feast-phase proportion of $10 \%$. This indicates that a fixed feast-phase proportion is unnecessary and the demanded operation condition by [39] is preferable. However, more experiments will be necessary to confirm these results. 
An influence of the cycle time length on the PHA composition is shown in Table 7, also. While all other experiments reached a higher PHB than PHV proportion a cycle time of $48 \mathrm{~h}$ or longer led to a higher PHV production. This could be due to the fact that the PHA accumulation bacteria produced PHB at first while the PHV production started later. As no samples were taken at low oxygen levels during the feast-phase and no uptake rate was measured for the VFAs (acetate, butyrate, valerate) during the experiments this presumption could not be confirmed.

The preferable operating conditions for the VFA production described in Chapter 3.1 provide VFA every day. Regarding the pairing of both productions steps (VFA and PHA production) and having in mind that with a cycle time of one day the highest PHA concentration $(28.4 \% \mathrm{CDW})$ was yielded, a CT $=24 \mathrm{~h}$ is favourable [42].

\subsection{Potential Analysis}

\subsubsection{Calculation for German Waste Water Treatment Plants}

Figure 8 shows the results for possible biopolymer production on German WWTPs. All material streams and reactor volumes in this figure are theoretical values showing the size of the flows, if the best substrate for acidification [34] of all German WWTPs with preliminary sedimentation potential (PSP $=$ more than 10,000 PE) would be used for PHA production.

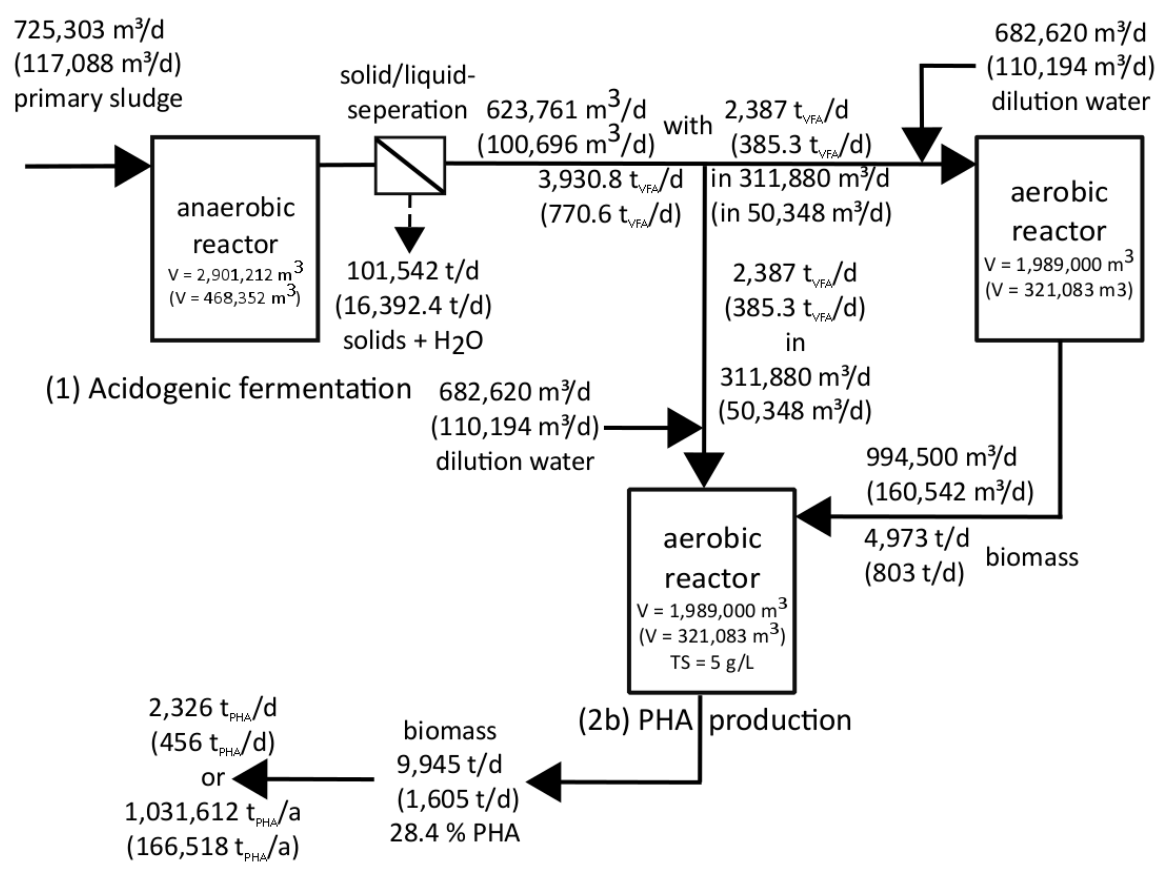

Figure 8. Biopolymer potential scheme for European and German (figures in brackets) WWTPs.

First of all, the calculation for the amount of primary sludge in Germany regarding the PEs (Table 1) connected to German WWTPs is shown in Equation (6).

$$
115,700,000 \mathrm{PE} \times 1.1 \frac{\mathrm{L}_{\mathrm{PS}}}{\mathrm{PE} \times \mathrm{d}}=1,272,700,000 \frac{\mathrm{L}_{\mathrm{PS}}}{\mathrm{d}}=127,270 \frac{\mathrm{m}^{3} \mathrm{PS}}{\mathrm{d}}
$$

Around $92 \%$ of PEs are coming from WWTPs with preliminary sedimentation potential (Table 1), on which a primary clarifier is installed or the construction of a primary clarifier would be preferable. Thus, the actual amount of primary sludge is calculated as follows:

$$
127,270 \frac{\mathrm{m}^{3} \mathrm{PS}}{\mathrm{d}} \times 92 \%=117,088.4 \frac{\mathrm{m}^{3} \mathrm{PS}}{\mathrm{d}}
$$


Using these data and the results of own experiments [34,42] and of Chapter 3.1 and 3.2 a calculation of the possible PHA production through various steps can be performed.

Implementing the best reactor operation method, using a retention time of 4 days and a daily withdrawal of $25 \%$ (Table 1) $117,088.4 \frac{\mathrm{m}^{3}}{\mathrm{~d}}$ acidified material could be used for PHA production every day (Equation (8)).

$$
117,088.4 \frac{\mathrm{m}^{3} \mathrm{PS}}{\mathrm{d}} \times 4 \mathrm{~d} \times 25 \frac{\%}{\mathrm{~d}}=117,088.4 \frac{\mathrm{m}^{3}}{\mathrm{~d}}
$$

The total solid (TS) concentration of the acidified material of $35 \frac{\mathrm{kg}}{\mathrm{m}^{3}}$ (Table 1) and the assumed residual moisture after de-watering via centrifuge of $75 \%$ leads to a daily acidified liquid production of $100,696 \frac{\mathrm{m}^{3}}{\mathrm{~d}}$ (Equations (9)-(11)).

$$
117,088.4 \frac{\mathrm{m}^{3}}{\mathrm{~d}} \times 35 \frac{\mathrm{kg}_{\mathrm{TS}}}{\mathrm{m}^{3}}=4,098,094 \frac{\mathrm{kg}_{\mathrm{TS}}}{\mathrm{d}}=4098.1 \frac{\mathrm{t}_{\mathrm{TS}}}{\mathrm{d}}
$$

The assumed residual moisture of $75 \%$ means that the calculated $4098.1 \frac{\mathrm{t}_{\mathrm{TS}}}{\mathrm{d}}$ biomass is $25 \%$ of the total mass separated by the centrifuge. Accordingly, $75 \%$ of the separated total mass is water. Assuming that the solid phase is completely separated it follows:

$$
4098.1 \frac{\mathrm{t}_{\mathrm{TS}}}{\mathrm{d}}+\frac{4098.1}{25} \frac{\frac{\mathrm{t}_{\mathrm{TS}}}{\mathrm{d}}}{\%} \times 75 \% \frac{\mathrm{t}_{\mathrm{H}_{2} \mathrm{O}}}{\mathrm{d}}=16,392.4 \frac{\mathrm{t}_{\mathrm{TS}+\mathrm{H}_{2} \mathrm{O}}}{\mathrm{d}}
$$

With an assumed average density of $1 \frac{\mathrm{t}}{\mathrm{m}^{3}}$ the amount of

$$
117,088.4 \frac{\mathrm{m}^{3}}{\mathrm{~d}}-\frac{16,392.4}{1} \frac{\frac{\mathrm{t}}{\mathrm{d}}}{\frac{\mathrm{t}}{\mathrm{m}^{3}}}=100,696 \frac{\mathrm{m}^{3}}{\mathrm{~d}}
$$

of acidified liquid is available for the PHA production step.

Regarding the average VFA concentration of $7653 \frac{\mathrm{mg}_{\mathrm{VFA}}}{\mathrm{L}}$ (Table 1$)$ the amount of VFA in the acidified water can be calculated (Equation (12)).

$$
7653 \frac{g_{\text {VFA }}}{\mathrm{m}^{3}} \times 100,696 \frac{\mathrm{m}^{3}}{\mathrm{~d}}=770.6 \frac{\mathrm{t}_{\mathrm{VFA}}}{\mathrm{d}}
$$

The substrate is divided into equal parts to both reactors $(2 \mathrm{a}$ and $2 \mathrm{~b})$ of the second production step so that each reactor is supplied with 50,348 $\frac{\mathrm{m}^{3}}{\mathrm{~d}}$ of acidified liquid (Equation (13)), containing 385.3 $\frac{t_{V F A}}{d}$ (Equation (14)).

$$
\begin{aligned}
& \frac{100,696 \frac{\mathrm{m}^{3}}{\mathrm{~d}}}{2}=50,348 \frac{\mathrm{m}^{3}}{\mathrm{~d}} \\
& \frac{770.6 \frac{\mathrm{t}_{\mathrm{VFA}}}{\mathrm{d}}}{2}=385.3 \frac{\mathrm{t}_{\mathrm{VFA}}}{\mathrm{d}}
\end{aligned}
$$

In order to achieve the required loading rate of $1.2 \frac{\mathrm{kg}_{\mathrm{VFA}}}{\mathrm{m}^{3} \times \mathrm{d}}$ in both reactors of the second production step, the volume of Reactor 2a (sum over Germany) and $2 b$ (sum over Germany) should be $321,083 \mathrm{~m}^{3}$ each (Equation (15)).

$$
\frac{385,300 \frac{\mathrm{kg}_{\mathrm{VFA}}}{\mathrm{d}}}{1.2 \frac{\mathrm{kg}_{\mathrm{VFA}}}{\mathrm{m}^{3} \times \mathrm{d}}}=321,083.3 \mathrm{~m}^{3}
$$

Reactor 2a is operated with a retention time of 2 days, a daily withdrawal of $50 \%$ of the reactors volume and a total solid concentration of TS $=5 \frac{\mathrm{g}_{\mathrm{TS}}}{\mathrm{L}}$ (Table 1). Due to the fact that there is no biomass sedimentation before the removal of the material, the withdrawn material can be considered as fully mixed. Therefore, the amount of bacteria must double every cycle to achieve a constant concentration of total solids. During the own experiments it was shown that this necessary condition was fulfilled [42]. 
The removal of $50 \%$ of the reactor volume leads to the amount of substrate, which has to be filled in the Reactor 2b every day (Equation (16)).

$$
321,083.3 \frac{\mathrm{m}^{3}}{\mathrm{~d}} \times 50 \%=160,541.7 \frac{\mathrm{m}^{3}}{\mathrm{~d}}
$$

The emptying and refilling process at the beginning of every cycle is represented in Figure 3. In order to reach a VFA concentration of $1.2 \frac{\mathrm{kg}_{\mathrm{VFA}}}{\mathrm{m}^{3} \times \mathrm{d}}$ and regarding to the fact that the VFA concentration at the end of a cycle is zero, a substrate with a VFA concentration of $2.4 \frac{\mathrm{kg}_{\mathrm{VFA}}}{\mathrm{m}^{3} \times \mathrm{d}}$ is needed if half of the reactors volume is exchanged.

Equation (16) shows the required amount of substrate for one day for one reactor regarding the needed VFA concentration. Hence the amount of VFA rich liquid of 50,348 $\frac{\mathrm{m}^{3}}{\mathrm{~d}}$ (Equation (13)) has to be diluted with 110,193.7 $\frac{\mathrm{m}^{3}}{\mathrm{~d}}$ fresh water (Equation (17)).

$$
160,541.7 \frac{\mathrm{m}^{3}}{\mathrm{~d}}-50,348 \frac{\mathrm{m}^{3}}{\mathrm{~d}}=110,193.7 \frac{\mathrm{m}^{3}}{\mathrm{~d}}
$$

When calculating the amount of dilution water it should be noted that the large amount of water is due to the reactors comparatively low total solid concentration of TS $=5 \frac{\mathrm{g}_{\mathrm{TS}}}{\mathrm{L}}$, which was installed during the experiments in [42]. This concentration is used for the potential analysis as well, to keep the calculation as close as possible to the operation conditions of the carried out experiments. Of course, a much higher solid concentration could be installed, leading to significantly smaller reactor volumes as well as less dilution water. As the amount of dilution water does not affect the result of the potential analysis it was kept.

As described, the biomass concentration in Reactor 2a was $5 \frac{g_{T S}}{L}$ at the end of a cycle. Regarding the withdrawal of $50 \%$ of the reactor's volume a total of

$$
321,083.3 \frac{\mathrm{m}^{3}}{\mathrm{~d}} \times 5 \frac{\mathrm{kg}_{\mathrm{TS}}}{\mathrm{m}^{3}} \times 5 \%=802,708.3 \frac{\mathrm{kg}_{\mathrm{TS}}}{\mathrm{d}}=802.71 \frac{\mathrm{t}_{\mathrm{TS}}}{\mathrm{d}}
$$

biomass is transferred into Reactor $2 \mathrm{~b}$. This reactor also had a dry matter content of $5 \frac{\mathrm{kg}_{\mathrm{TS}}}{\mathrm{m}^{3}}$ after the PHA production step (Table 1). Considering a cycle time of one day and the volume of $321,083 \mathrm{~m}^{3}$, the amount of biomass in Reactor $2 \mathrm{~b}$ sums up to (Equation (19)):

$$
\frac{321,083.3 \mathrm{~m}^{3}}{1 \mathrm{~d}} \times 5 \frac{\mathrm{kg}_{\mathrm{TS}}}{\mathrm{m}^{3}}=1,605,416.5 \frac{\mathrm{kg}_{\mathrm{TS}}}{\mathrm{d}}=1605.4 \frac{\mathrm{t}_{\mathrm{TS}}}{\mathrm{d}}
$$

With the reached PHA concentration of $28.4 \%$ of the cell dry weight (CDW) [42] the daily amount of biopolymer is calculated in Equation (20).

$$
1605.4 \frac{\mathrm{t}_{\mathrm{TS}}}{\mathrm{d}} \times 28.4 \% \frac{\mathrm{PHA}}{\mathrm{TS}}=455.9 \frac{\mathrm{t}_{\mathrm{PHA}}}{\mathrm{d}}
$$

Finally, the possible annual amount of PHA production on German waste water treatment plants can be calculated in Equation (21).

$$
455.9 \frac{t_{P H A}}{d} \times 365.25 \frac{d}{a}=166,517.5 \frac{t_{P H A}}{a}
$$

Dividing the reactor volume (sum of all production stages) of $1,110,518 \mathrm{~m}^{3}$ by the people's equivalent with preliminary sedimentation potential of 106.56 Mio. PE (Table 1) results in a reactor volume (sum of all production stages) per capita of around 10.4 L/PE. Each PE can contribute to the production of $1.6 \mathrm{~kg}_{\mathrm{PHA}} /(\mathrm{PE} \times \mathrm{a})$. Keeping in mind that the aeration tank volume on a WWTP with 100,000 PE sums up to $10,000 \mathrm{~m}^{3}-15,000 \mathrm{~m}^{3}$ an additional reactor volume of approximately 
$1050 \mathrm{~m}^{3}$ would be needed for the biopolymer production, only. Thus, the extra volume would not be disproportional.

\subsubsection{Estimation for European Waste Water Treatment Plants}

The Biopolymer potential for European WWTPs are calculated similar to Section 3.3.1 and also shown in Figure 8.

As there are missing data about the amount of connected persons (PEs) for many EU member states as well as about the amount of municipal waste water, it is impossible to calculate the EU-wide production of primary sludge analogous to Equations (6) and (7). However, there are data for all 28 EU member states regarding the production of sewage sludge. These data show the dry weight of sewage sludge in $\frac{t_{T S}}{a}$ (Table 1) and hence their unit must be transferred into $\frac{\mathrm{m}^{3}}{\mathrm{a}}$ (Equation (22)) to compare them with the data used for German WWTP in Equation (6). Therefore, an average total solid concentration of $15 \frac{\mathrm{g}_{\mathrm{TS}}}{\mathrm{L}}$ or $66.67 \frac{\mathrm{m}^{3}}{\mathrm{t}_{\mathrm{TS}}}$ for European sewage sludge (primary and secondary) is assumed.

$$
13,245,180 \frac{\mathrm{t}_{\mathrm{TS}}}{\mathrm{a}} \times 66.67 \frac{\mathrm{m}^{3}}{\mathrm{t}_{\mathrm{TS}}}=883,056,150 \frac{\mathrm{m}^{3}}{\mathrm{a}}
$$

On the assumption that the proportion of primary sludge in the amount of sewage sludge is more or less constant in all member states, the percentage can be calculated (Equation (25)) using the theoretical yearly amount of primary sludge produced in Germany (Equations (6) and (23)) and the yearly amount of German sewage sludge (Table 1) (Equation (24)).

$$
\begin{gathered}
115,700,000 \mathrm{PE} \times 1.1 \frac{\mathrm{LPS}}{\mathrm{PE} \times \mathrm{d}} \times 365.25 \frac{\mathrm{d}}{\mathrm{a}}=46,485,367.5 \frac{\mathrm{m}^{3} \mathrm{PS}}{\mathrm{a}} \\
1,815,150 \frac{\mathrm{t}_{\mathrm{TS}}}{\mathrm{a}} \times 66.67 \frac{\mathrm{m}^{3}}{\mathrm{t}_{\mathrm{TS}}}=121,016,051 \frac{\mathrm{m}^{3}}{\mathrm{a}} \\
\frac{46,485,367.5 \frac{\mathrm{m}^{3} \mathrm{PS}}{\mathrm{a}}}{121,016,051 \frac{\mathrm{m}^{3}}{\mathrm{a}}} \times 100 \%=38.4 \%
\end{gathered}
$$

Assuming that not all European waste water treatment plants are equipped with a primary clarifier, the proportion of primary sludge is rounded off to $30 \%$, so that the yearly amount of European primary sludge sums up to 265 Mio. $\frac{\mathrm{m}^{3} \mathrm{PS}}{\mathrm{a}}$ (Equation (26)) or 725,303 $\frac{\mathrm{m}^{3} \mathrm{PS}}{\mathrm{d}}$ (Equation (27)).

$$
\begin{gathered}
883,056,151 \frac{\mathrm{m}^{3} \mathrm{PS}}{\mathrm{a}} \times 30 \%=264,916,845.3 \frac{\mathrm{m}^{3} \mathrm{PS}}{\mathrm{a}} \\
\frac{264,916,845.3 \frac{\mathrm{m}^{3} \mathrm{PS}}{\mathrm{a}}}{365.25 \frac{\mathrm{d}}{\mathrm{a}}}=725,302.8 \frac{\mathrm{m}^{3} \mathrm{PS}}{\mathrm{d}}
\end{gathered}
$$

By now, the European biopolymer potential can be calculated analogous to Equations (8)-(21). The amount of acidified material is:

$$
725,303 \frac{\mathrm{m}^{3} \mathrm{PS}}{\mathrm{d}} \times 4 \mathrm{~d} \times 25 \frac{\%}{\mathrm{~d}}=725,303 \frac{\mathrm{m}^{3}}{\mathrm{~d}}
$$

Using Equations (9)-(11) the amount of acidified liquid can be calculated (Equation (31)):

$$
\begin{gathered}
725,303 \frac{\mathrm{m}^{3}}{\mathrm{~d}} \times 35 \frac{\mathrm{kg}_{\mathrm{TS}}}{\mathrm{m}^{3}}=25,385,605 \frac{\mathrm{kg}_{\mathrm{TS}}}{\mathrm{d}}=25,385.6 \frac{\mathrm{t}_{\mathrm{TS}}}{\mathrm{d}} \\
25,385.6 \frac{\mathrm{t}_{\mathrm{TS}}}{\mathrm{d}}+\frac{25,385.6 \frac{\mathrm{t}_{\mathrm{TS}}}{\mathrm{d}}}{25 \%} \times 75 \% \frac{\mathrm{t}_{\mathrm{H}_{2} \mathrm{O}}}{\mathrm{d}}=101,542.4 \frac{\mathrm{t}_{\mathrm{TS}+\mathrm{H} 2 \mathrm{O}}}{\mathrm{d}}
\end{gathered}
$$


With an average density of $1 \frac{\mathrm{t}}{\mathrm{m}^{3}}$

$$
725,303 \frac{\mathrm{m}^{3}}{\mathrm{~d}}-\frac{101,542.4 \frac{\mathrm{t}}{\mathrm{d}}}{1 \frac{\mathrm{t}}{\mathrm{m}^{3}}}=623,760.6 \frac{\mathrm{m}^{3}}{\mathrm{~d}}
$$

of acidified liquid can be used within the second PHA production step. This leads to the amount of VFAs in the acidified water (Equation (32)):

$$
7653 \frac{g_{V F A}}{m^{3}} \times 623,760.6 \frac{\mathrm{m}^{3}}{\mathrm{~d}}=4773.6 \frac{\mathrm{t}_{\mathrm{VFA}}}{\mathrm{d}}
$$

Analogous to Equations (13) and (14) both reactors of the second production step are supplied with $311,880 \frac{\mathrm{m}^{3}}{\mathrm{~d}}$ (Equation (33)) of acidified liquid containing $2386.8 \frac{\mathrm{tVFA}}{\mathrm{d}}$ (Equation (34)).

$$
\begin{aligned}
\frac{623,760.6 \frac{\mathrm{m}^{3}}{\mathrm{~d}}}{2} & =311,880.3 \frac{\mathrm{m}^{3}}{\mathrm{~d}} \\
\frac{4773.6 \frac{\mathrm{t}_{\mathrm{VFA}}}{\mathrm{d}}}{2} & =2386.8 \frac{\mathrm{t}_{\mathrm{VFA}}}{\mathrm{d}}
\end{aligned}
$$

The reactor volumes (Equation (35)) can be calculated analogous to Equation (15):

$$
\frac{2,386,800 \frac{\mathrm{kg}_{\mathrm{VFA}}}{\mathrm{d}}}{1.2 \frac{\mathrm{kg}_{\mathrm{VFA}}}{\mathrm{m}^{3} \times \mathrm{d}}}=1,989,000 \mathrm{~m}^{3}
$$

The daily substrate amount for one reactor is (Equation (36)):

$$
1,989,000 \frac{\mathrm{m}^{3}}{\mathrm{~d}} \times 50 \%=994,500 \frac{\mathrm{m}^{3}}{\mathrm{~d}}
$$

Analogous to Equation (17) the amount of dilution water can be calculated (Equation (37)):

$$
994,500 \frac{\mathrm{m}^{3}}{\mathrm{~d}}-311,880.3 \frac{\mathrm{m}^{3}}{\mathrm{~d}}=682,619.7 \frac{\mathrm{m}^{3}}{\mathrm{~d}}
$$

With a withdrawal of $50 \%$ a biomass transfer to Reactor $2 \mathrm{~b}$ of $4094.58 \frac{\mathrm{t}_{\mathrm{TS}}}{\mathrm{d}}$ is necessary (Equation (38)).

$$
1,989,000 \frac{\mathrm{m}^{3}}{\mathrm{~d}} \times 5 \frac{\mathrm{kg}_{\mathrm{TS}}}{\mathrm{m}^{3}} \times 50 \%=4,972,500 \frac{\mathrm{kg}_{\mathrm{TS}}}{\mathrm{d}}=4972.5 \frac{\mathrm{t}_{\mathrm{TS}}}{\mathrm{d}}
$$

With the described total solid concentration of $5 \frac{\mathrm{kg}_{\mathrm{TS}}}{\mathrm{m}^{3}}$ after the PHA production the amount of biomass in Reactor $2 \mathrm{~b}$ is (Equation (39)):

$$
1,989,000 \mathrm{~m}^{3} \times 5 \frac{\mathrm{kg}_{\mathrm{TS}}}{\mathrm{m}^{3}}=9,945,000 \frac{\mathrm{kg}_{\mathrm{TS}}}{\mathrm{d}}=9945 \frac{\mathrm{t}_{\mathrm{TS}}}{\mathrm{d}}
$$

With a cycle time of one day and the reached PHA concentration of $28.4 \%$ CDW (Table 1) the daily amount of PHA sums up to (Equation (40)):

$$
9945 \frac{\mathrm{t}_{\mathrm{TS}}}{\mathrm{d}} \times 28.4 \% \frac{\mathrm{PHA}}{\mathrm{TS}}=2824.4 \frac{\mathrm{t}_{\mathrm{PHA}}}{\mathrm{d}}
$$


Finally, the possible annual amount of PHA production on European waste water treatment plants can be calculated in Equation (41).

$$
2824.4 \frac{t_{P H A}}{d} \times 365.25 \frac{d}{a}=1,031,612.1 \frac{t_{P H A}}{a}
$$

\subsubsection{Summary of the Results and Optimization Potential}

The market for biopolymers is predicted to grow continuously [43]. In 2016, a worldwide biopolymer production of 4.16 Mio. $\frac{t}{a}$, of which $861,120 \frac{t}{a}$ or $20.7 \%$ [43] suit the criteria of the stringent definition for biopolymers, introduced in Chapter 1, were achieved. Taking Equation (21) into account approximately $4.0 \%$ of the worldwide biopolymer production (bio- and non-biodegradable) could be produced just by using primary sludge from German WWTPs. Around 19.3\% of the worldwide biopolymers could be produced on WWTPs in Germany considering the stringent definition, only.

For the biopolymer production on European WWTPs (Equation (41)) approximately $24.7 \%$ of 2016 's worldwide biopolymer production (bio- and non-biodegradable) or around $119.8 \%$ of 2016 's worldwide biopolymer production due to the stringent definition could be produced.

Assuming an improved PHA production with an achievable PHA concentration of $0.5 \frac{\mathrm{g}_{\mathrm{PHA}}}{\mathrm{g}_{\mathrm{VSS}}}$ [44] or even around $60 \%$ CDW [45,46] a total amount of 2,179,446.8 $\frac{\mathrm{t}_{\mathrm{PHA}}}{\mathrm{a}}$ (Equation (42)) could be produced on European WWTPs by using primary sludge, only.

$$
9945 \frac{\mathrm{t}_{\mathrm{TS}}}{\mathrm{d}} \times 60 \% \times 36,525 \frac{\mathrm{d}}{\mathrm{a}}=2,179,446.8 \frac{\mathrm{t}_{\mathrm{PHA}}}{\mathrm{a}}
$$

Thus, approximately $52.4 \%$ of 2016's worldwide biopolymer production (bio- and non-biodegradable) or $253.1 \%$ of 2016 's worldwide biopolymer production due to the stringent definition could be produced in an improved production on WWTPs in the EU.

A large proportion of polymers (biopolymers and those from synthetic production) is used for packing materials. The PHAs feature similar characteristics like polypropylene (PP), which is the mostly sold plastic in the EU with 18.8\% (around 8.6 Mio. $\frac{t}{a}$ ) market share in 2012 [47]. The potential analysis for Germany equates to approximately $1.9 \%$ of the EUs PP production. Using the calculation for the EU for PHA production from primary sludge around $12.0 \%$ of the conventional PP sold in the EU could be substituted which is a significant potential.

\subsubsection{Plausibility Analysis}

As some input parameters do have a strong effect to the calculations, a plausibility analysis was carried out. All critical parameters, like total solid concentration of the primary sludge, the daily amount of primary sludge per PE, or the daily amount of primary sludge per PE were analysed and considered plausible. A more detailed description of the plausibility analysis can be found in [28].

\section{Summary and Conclusions}

From the results, it could be concluded that the production of high amounts of VFAs with a stable VFA composition on a WWTP is possible. Using different raw materials shows a strong influences on degree of acidification and VFA composition. The VFA production and composition is strongly influenced by a $\mathrm{pH}$-level change in the reactor. A semi-continuous operation method of the reactor with a short RT and small WD is preferable. With primary sludge as raw material no biomass recirculation is needed during the fermentation process.

The results showed that the produces VFA are suitable for PHA production in a second stage. This amount of PHA produced is strongly influenced by the reactors operating conditions (temperature, $\mathrm{pH}$-level and substrate concentration), while the PHA composition is influenced by cycle time changes. At preferred conditions, a stable PHB/PHV composition was reached and both PHAs were produced in nearly the same proportion. 
Nevertheless, further research is needed to couple both processes for constant and long term PHA production and for upscaling.

The results of the presented potential analysis clearly indicate the possibility to produce large amounts of PHAs on German and European WWTPs. It has been shown that municipal WWTPs could be used as a significant source for biopolymers and waste water is an important substituent for plant-based raw materials in the PHA production.

More than twice the amount of 2016's worldwide biopolymer production could be produced on European WWTPs with an upgraded operation. Thus, the production of biopolymers on waste water treatment plants contribute to a recycling of the organic material contained in waste water.

Acknowledgments: We thank the WILLY-HAGER-STIFTUNG, Stuttgart for funding the research project.

Author Contributions: Timo Pittmann and Heidrun Steinmetz conceived and designed the experiments; Timo Pittmann performed the experiments; Timo Pittmann and Heidrun Steinmetz analyzed the data; Timo Pittmann contributed reagents/materials/analysis tools; Timo Pittmann and Heidrun Steinmetz wrote the paper.

Conflicts of Interest: The authors declare no conflict of interest. The funding sponsor had no role in the design of the experiments; in the collection, analyses, or interpretation of date; in the writing of the manuscript, or the decision to publish the results.

\section{References}

1. United Nations Environment Programme (UNEP). Marine Litter-A Global Challenge; UNEP: Nairobi, Kenia, 2009.

2. Jendrossek, D.U.; Handrick, R. Microbial degradation of polyhydroxyalkanoates. Annu. Rev. Microbiol. 2002, 56, 403-432. [CrossRef] [PubMed]

3. Choi, G.G.; Kim, H.W.U.; Rhee, Y.H. Enzymatic and non-enzymatic degradation of poly(3-hydroxybutyrateco-3-hydroxyvalerate) copolyesters produced by Alcaligenes sp. MT-16. J. Microbiol. 2004, 42, 346-352. [PubMed]

4. Pittmann, T. Herstellung von Biokunststoffen aus Stoffströmen einer kommunalen Kläranlage. Dissertation thesis, Institute for Sanitary Engineering, Water Quality and Solid Waste Management, Stuttgart, Germany, 2015.

5. Nikodinovic-Runic, J.U.; Guzik, M. Carbon-rich wastes as feedstocks for biodegradable polymer (polyhydroxyalkanoate) production using bacteria. Adv. Appl. Microbiol. 2013, 84, 139-200. [CrossRef] [PubMed]

6. Cavalheiro, J.M.B.T.; de Almeida, C.M.M.D.; Grandfils, C.; da Fonseca, M.M.R. Poly(3-hydroxybutyrate) production by Cupriavidus necator using waste glycerol. Process Biochem. 2009, 44, 509-515. [CrossRef]

7. Zinn, M.U.; Hany, R. Tailored material properties of polyhydroxyalkanoates through biosynthesis and chemical modification. Adv. Eng. Mater. 2005, 7, 408-411. [CrossRef]

8. Akaraonye, E.; Keshavarz, T.U.; Roy, I. Production of polyhydroxyalkanoates: The future green materials of choice. J. Chem. Technol. Biotechnol. 2010, 85, 732-743. [CrossRef]

9. Steinbuechel, A. Angewandte Mikrobiologie, Biopolymere und Vorstufen; Springer: Berlin/Heidelberg, Germany, 2005.

10. Faulstich, M.; Greiff, K.B. Klimaschutz durch biomasse, ergebnisse des SRU-sondergutachtens. Umweltwissenschaften und Schadstoff-Forschung 2007. [CrossRef]

11. Bengtsson, S.; Werker, A.; Christensson, M.; Welander, T. Production of polyhydroxyalkanoates by activated sludge treating a paper mill wastewater. Bioresour. Technol. 2008, 99, 509-516. [CrossRef] [PubMed]

12. Morgan-Sagastume, F.; Valentino, F.; Hjort, M.; Cirne, D.; Karabegovic, L.; Geradin, F.; Dupont, O.; Johansson, P.; Karlsson, A.; Magnusson, P.; et al. Biopolymer production from sludge and municipal wastewater treatment. Water Sci. Technol. 2014, 69, 177-184. [CrossRef] [PubMed]

13. Chakravarty, P.; Mhaisalkar, V.; Chakrabarti, T. Study on poly-hydroxy-alkanoate (PHA) production in pilot scale continuous mode wastewater treatment system. Bioresour. Technol. 2010, 101, 2896-2899. [CrossRef] [PubMed] 
14. Chua, A.; Takabatake, H.; Satoh, H.; Mino, T. Production of polyhydroxyalkanoates (PHA) by activated sludge treating municipal wastewater: Effect of $\mathrm{pH}$, sludge retention time (SRT), and acetate concentration in influent. Water Res. 2003, 37, 3602-3611. [CrossRef]

15. Chua, H.; Yu, P. Production of biodegradable plastics from chemical wastewater-A novel method to reduce excess activated sludge generated from industrial wastewater treatment. Water Sci. Technol. 1999, 39, 273-280. [CrossRef]

16. Dionisi, D.; Majone, M.; Papa, V.; Beccari, M. Biodegradable polymers from organic acids by using activated sludge enriched by aerobic periodic feeding. Biotechnol. Bioeng. 2004, 85, 569-579. [CrossRef] [PubMed]

17. Reddy, S.V.; Thirumala, M.; Reddy, T.K.; Mahmood, S.K. Isolation of bacteria producing polyhydroxyalkanoates (PHA) from municipal sewage sludge. World J. Microbiol. Biotechnol. 2008, 24, 2949-2955. [CrossRef]

18. Lemos, P.C.; Serafim, L.S.; Reis, M. Synthesis of polyhydroxyalkanoates from different short-chain fatty acids by mixed cultures submitted to aerobic dynamic feeding. J. Biotechnol. 2006, 122, 226-238. [CrossRef] [PubMed]

19. Albuquerque, M.; Eiroa, M.; Torres, C.; Nunes, B.R.; Reis, M. Strategies for the development of a side stream process for polyhydroxyalkanoate (PHA) production from sugar cane molasses. J. Biotechnol. 2007, 130, 411-421. [CrossRef] [PubMed]

20. Albuquerque, M.G.E.; Martino, V.; Pollet, E.; Avérous, L.; Reis, M. Mixed culture polyhydroxyalkanoate (PHA) production from volatile fatty acid (VFA)-rich streams: Effect of substrate composition and feeding regime on PHA productivity, composition and properties. J. Biotechnol. 2011, 151, 66-76. [CrossRef] [PubMed]

21. Bengtsson, S. The utilization of glycogen accumulating organisms for mixed culture production of polyhydroxyalkanoates. Biotechnol. Bioeng. 2009, 104, 698-708. [CrossRef] [PubMed]

22. Bengtsson, S.; Pisco, A.R.; Reis, M.; Lemos, P.C. Production of polyhydroxyalkanoates from fermented sugar cane molasses by a mixed culture enriched in glycogen accumulating organisms. J. Biotechnol. 2010, 145, 253-263. [CrossRef] [PubMed]

23. Albuquerque, M.; Concas, S.; Bengtsoon, S.; Reis, M. Mixed culture polyhydroxyalkanoates production from sugar cane molasses: The use of a 2-stage CSTR system for culture selection. Bioresour. Technol. 2010, 101, 7112-7122. [CrossRef] [PubMed]

24. Choi, J.; Lee, S.Y. Process analysis and economic evaluation for Poly(3-hydroxybutyrate) production by fermentation. Bioprocess Eng. 1997, 17, 335. [CrossRef]

25. Dionisi, D.; Carucci, G.; Petrangeli Papini, M.; Riccardi, C.; Majone, M.; Carrasco, F. Olive oil mill effluents as a feedstock for production of biodegradable polymers. Water Res. 2005, 39, 2076-2084. [CrossRef] [PubMed]

26. Dionisi, D.; Majone, M.; Vallini, G.; Di Gregorio, S.; Beccari, M. Effect of the applied organic load rate on biodegradable polymer production by mixed microbial cultures in a sequencing batch reactor. Biotechnol. Bioeng. 2005, 93, 76-88. [CrossRef] [PubMed]

27. Johnson, K.; Jiang, Y.; Kleerebezem, R.; Muyzer, G.; van Loosdrecht, M. Enrichment of a mixed bacterial culture with a high polyhydroxyalkanoate storage capacity. Biomacromolecules 2009, 10, 670-676. [CrossRef] [PubMed]

28. Pittmann, T.; Steinmetz, H. Potential for polyhydroxyalkanoate production on German or European municipal waste water treatment plants. Bioresour. Technol. 2016, 214, 9-15. [CrossRef] [PubMed]

29. DWA: 28th Performance Comparison of Municipal Waste Water Treatment Plants. 2016. Available online: http://de.dwa.de/tl_files/_media/content/PDFs/1_Aktuelles/leistungsvergleich_2015.PDF (accessed on 2 June 2017).

30. Eurostat: Sewage Sludge Production and Disposal. Available online: http://ec.europa.eu/eurostat/data/ database?nodecode=envwwspd (accessed on 2 June 2017).

31. Chen, H.; Meng, H.; Nie, Z.; Zhang, M. Polyhydroxyalkanoate production from fermented volatile fatty acids: Effect of $\mathrm{pH}$ and feeding regimes. Bioresour. Technol. 2013, 128, 533-538. [CrossRef] [PubMed]

32. Mengmeng, C.; Hong, C.; Qingliang, Z.; Shirley, S.N.; Jie, R. Optimal production of polyhydroxyalkanoates (PHA) in activated sludge fed by volatile fatty acids (VFAs) generated from alkaline excess sludge fermentation. Bioresour. Technol. 2009, 100, 1399-1405. [CrossRef] [PubMed] 
33. Bengtsson, S.; Hallquist, J.; Werker, A.; Welander, T. Acidogenic fermentation of industrial wastewaters. Effects of chemostat retention time and $\mathrm{pH}$ on volatile fatty acids production. Biochem. Eng. J. 2008, 40, 492-499. [CrossRef]

34. Pittmann, T.; Steinmetz, H. Influence of operating conditions for volatile fatty acids enrichment as a first step for polyhydroxyalkanoate production on a municipal waste water treatment plant. Bioresour. Technol. 2013, 148, 270-276. [CrossRef] [PubMed]

35. Queirós, D.; Rossetti, S.; Serafim, L.S. PHA production by mixed cultures: A way to valorize wastes from pulp industry. Bioresour. Technol. 2014, 157, 197-205. [CrossRef] [PubMed]

36. Dimensioning of a Single-Stage Biological Wastewater Tretment Plant; Publishing Company of ATV-DVWK, Water, Wastewater, Waste: Hennef, Germany, 2000; Standard ATV-DVWK-A131. [CrossRef]

37. Serafim, L.S.; Lemos, P.C.; Oliveira, R.; Reis, M. Optimization of polyhydroxybutyrate production by mixed cultures submitted to aerobic dynamic feeding conditions. Biotechnol. Bioeng. 2004, 87, 145-160. [CrossRef] [PubMed]

38. Bischofsberger, W.; Dichtl, N.; Rosenwinkel, K.-H.; Seyfried, C.F.; Bohnke, B. Anaerobtechnik; Springer: Berlin/Heidelberg, Germany, 2015. [CrossRef]

39. Morgan-Sagastume, F.; Karlsson, A.; Johansson, P.; Pratt, S.; Boon, N.; Lant, P.; Werker, A. Production of polyhydroxyalkanoates in open, mixed cultures from a waste sludge stream containing high levels of soluble organics, nitrogen and phosphorus. Water Res. 2010, 44, 5196-5211. [CrossRef] [PubMed]

40. Johnson, K.; Kleerebezem, R.; van Loosdrecht, M.C.M. Influence of ammonium on the accumulation of polyhydroxybutyrate (PHB) in aerobic open mixed cultures. J. Biotechnol. 2010, 147, 73-79. [CrossRef] [PubMed]

41. Wen, Q.; Chen, Z.; Tian, T.; Chen, W. Effects of phosphorus and nitrogen limitation on PHA production in activated sludge. J. Environ. Sci. 2010, 22, 1602-1607. [CrossRef]

42. Pittmann, T.; Steinmetz, H. Polyhydroxyalkanoate production as a side stream process on a municipal waste water treatment plant. Bioresour. Technol. 2014, 167, 297-302. [CrossRef] [PubMed]

43. European Bioplastik e.V. Bioplastics. Bioplastics-Facts and Figures. 2016. Available online: http://docs. european-bioplastics.org/publications/EUBP_Facts_and_figures.pdf (accessed on 19 April 2017).

44. Morgan-Sagastume, F.; Hjort, M. Integrated production of polyhydroxyalkanoates (PHAs) with municipal wastewater and sludge treatment at pilot scale. Bioresour. Technol. 2015, 181, 78-89. [CrossRef] [PubMed]

45. Jia, Q.; Wang, H.; Wang, X. Dynamic synthesis of polyhydroxyalkanoates by bacterial consortium from simulated excess sludge fermentation liquid. Bioresour. Technol. 2013, 140, 328-336. [CrossRef] [PubMed]

46. Jia, Q.; Xiong, H. Production of polyhydroxyalkanoates (PHA) by bacterial consortium from excess sludge fermentation liquid at laboratory and pilot scales. Bioresour. Technol. 2014, 171, 159-167. [CrossRef] [PubMed]

47. Bonten, C. Kunststofftechnik. Einführung und Grundlagen; Hanser Carl Verlag: München, Germany, 2014. 